Article

\title{
Emergence and Evolution of Anthropogenic Landscapes in the Western Mediterranean and Adjacent Atlantic Regions
}

\author{
Virginia Iglesias $1,2, * \mathbb{C}$, Boris Vannière ${ }^{1,3}\left[\right.$ and Isabelle Jouffroy-Bapicot ${ }^{1,3}$ \\ 1 Maison des Sciences de l'Homme et de l'Environnement, CNRS, Université Bourgogne Franche-Comté, \\ 25000 Besançon, France; boris.vanniere@univ-fcomte.fr (B.V.); Isabelle.Jouffroy@univ-fcomte.fr (I.J.-B.) \\ 2 Earth Lab, University of Colorado, Boulder, CO 80303, USA \\ 3 Chrono-Environnement, CNRS, Université Bourgogne Franche-Comté, 25000 Besançon, France \\ * Correspondence: virginia.iglesias@colorado.edu
}

Received: 10 August 2019; Accepted: 12 October 2019; Published: 15 October 2019

\begin{abstract}
Socio-ecological systems are complex, dynamic structures driven by cross-scale interactions between climate, disturbance and subsistence strategies. We synthetize paleoecological data to explore the emergence and evolution of anthropogenic landscapes in southwestern Europe and northern Africa. Specifically, we estimate trends in vegetation and fire, and assess how changes in climate and resource exploitation altered ecosystem dynamics over the last 10,000 years. Pollen data reveal that a complex vegetation mosaic resulted from the conversion of forests into areas suitable for crops, especially after 7000 cal yr BP. Cross-scale analysis shows a progressive decoupling of climate and ecosystem trajectories, which displayed an overall south-to-north time-transgressive pattern consistent with models of population expansion. As human impact increased, so did the use of fire, and after $4000 \mathrm{cal} \mathrm{yr} \mathrm{BP}$, levels of biomass burning became homogeneous across the region. This region-wide rise in burning suggests that land-management overrode the effects of climate, fuel and topography. Thus, while increasing the returns and predictability of resources, rapidly-growing communities created a new form of frequent and extensive disturbance that led to profound and persistent changes in the landscape, including shrub encroachment, increased erosion and soil impoverishment.
\end{abstract}

Keywords: deforestation; fire; human impact; climate change; land-use; Holocene; preindustrial; Anthropocene

\section{Introduction}

Throughout the geological history of Earth, climate has been a key driver of biophysical processes at a variety of scales, from landform transformation and biological evolution, to biome reorganization and geochemical cycles. Modern ecosystems have been shaped by these processes, as well as by the legacy effects of millennia of anthropic resource exploitation [1]. In particular, the emergence of agriculture and the changes in land-cover associated with its spread may have altered, not only the local distribution of vegetation, but also greenhouse-gas concentrations and global climate [2].

In the Mediterranean Basin, for example, the expansion of agriculture is believed to have started over 11,000 years ago and reached southwestern Europe at ca. $8000 \mathrm{cal}$ yr BP (calibrated years before present; [3]). Pollen- and charcoal-based reconstructions show coeval deforestation that resulted in the loss of up to $60 \%$ of Early Holocene European forests (10,000-8000 cal yr BP) by preindustrial times [4], as well as altered fire regimes [5]. This association suggests that, rather than pristine landscapes, anthropic ecosystems have dominated the continent for thousands of years. 
Human-environment relationships, however, are not unidirectional. Processes as diverse as food production, migrations, settlement patterns and the domestication of species have been attributed in part to environmental change (e.g., [6,7]). Socio-environmental systems (SES) thus emerge as complex, dynamic structures driven by changes in climate, disturbance regimes and subsistence strategies. For this reason, the understanding of these systems informs not only on ecosystem responses to climate and anthropogenic change, but also provides insights into the time-variant social, economic, technological and esthetic forces involved in their evolution.

In this study, we explore the emergence and evolution of anthropogenic landscapes in the Western Mediterranean and Adjacent Atlantic Regions (WMAAR; Figure 1). In order to account for both the climate and human dimensions of ecosystem change, we synthetized publicly-available pollen and charcoal data to (i) estimate Holocene trends in fire, vegetation and land-use at the regional and sub-regional scales. The results are then compared with independent, published models of area burned and land-cover to (ii) assess how and at what scales the anthropogenic impact and climate variability altered vegetation and fire dynamics over the last 10,000 years. We thus expect to harness the power of empirical data to describe past environmental conditions, and use data-model comparisons to offer process-based representations of climate-fire-vegetation linkages that can be interrogated with ecological goals.

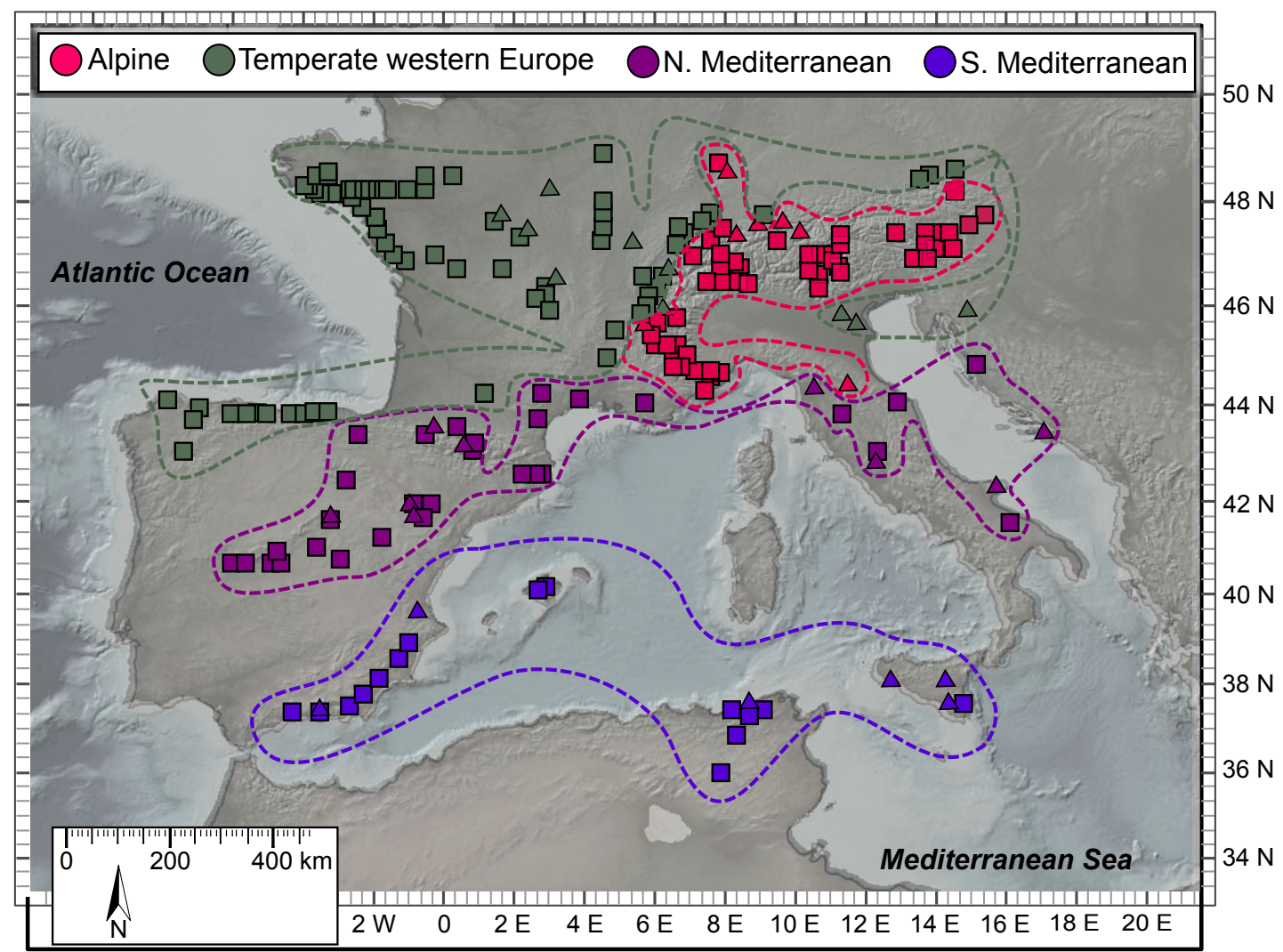

Figure 1. Western Mediterranean and Adjacent Atlantic Regions (WMAAR). The dashed lines show the approximate boundaries of the sub-regions identified with a classification tree. Squares and triangles depict the location of the sites employed in the vegetation and fire reconstructions, respectively (Table S1).

\section{Materials and Methods}

\subsection{Regional Setting}

The Mediterranean Sea is a semi-enclosed, relatively deep body of water that constitutes a large reservoir of heat and moisture. Climate in the surrounding landmasses is characterized by warm/hot, 
dry summers and mild/cold, humid winters. Due to the latitudinal position of the region, precipitation is mainly associated with systems migrating eastwards along the storm tracks.

Dry summer conditions result from the pole-ward migration of the Inter-tropical Convergence Zone (ITCZ), which brings southwestern Europe under the influence of the Azores subtropical high, and blocks the circulation of the mid-latitude westerly winds. Conversely, the southward shift of the ITCZ in winter months allows humid Atlantic air masses to reach the area, leading to increased precipitation [8].

Although the sea and the ocean have a strong effect on atmospheric circulation and cyclogenesis, the Western Mediterranean and Adjacent Atlantic Regions (WMAAR) cannot be defined as a climatically homogeneous area [9]. An overall north-to-south temperature and precipitation gradient prevails in the region, with longer, warmer and drier summers south of latitude $40^{\circ} \mathrm{N}$ [10]. The gradient is altered by complex orography, which, combined with land-sea interactions and local processes, results in a mosaic of climates. As a consequence, annual precipitation ranges from $<200 \mathrm{~mm}$ in arid environments to the south to $>3500 \mathrm{~mm}$ in the most humid alpine watersheds. A long history of human occupation adds further complexity to the landscape, and humid alpine ecosystems, hot subtropical deserts and temperate maritime forests co-exist in the area [11,12].

\subsection{Rationale}

Environmental trajectories result from cross-scale interactions, wherein the higher levels of interconnections constrain the lower ones to various degrees [13]. Climate is a large-scale driver of ecosystem dynamics. If climate requirements are met, site-specific factors are thought to govern vegetation structure at the watershed-scale. Paleoecological studies support this assertion by showing that ecosystem development at the regional-scale can be attributed to long-term changes in insolation (incoming solar radiation) and atmospheric circulation (e.g., [14]). Suitable climate consequently emerges as a necessary condition for vegetation establishment and persistence, but by itself, this does not provide a sufficient set of mechanisms to explain the distribution of plant communities $[15,16]$. Based on the corollary of this theoretical framework, i.e., that the relative importance of a given process is scale-dependent, synthesis of proxy data has allowed the identification of the climate signal on vegetation and fire at sub-continental scales [17-21]. We followed a similar approach to assess the relative role of climate and anthropogenic impact in driving regional ecosystem dynamics during the last 10,000 years. Specifically, we first reconstructed regional trends in biomass burning and vegetation. We then visually compared the estimated trends with independent models of the area burned and potential woody biomass for southwestern Europe [5,22,23]. Given that the model of area burned and that of the potential woody biomass are driven by climate, we expect a close correspondence between our data-based reconstructions and the simulations at times when climate was the main driver of ecosystem dynamics. Conversely, a mismatch between the models and the estimated trends in fire and/or woody taxa abundance is interpreted as possible evidence of large-scale anthropogenic impact and/or strong positive vegetation-fire feedbacks that override the direct effects of climate.

To further explore human-environment interactions, we also considered modeled woody biomass under the widely used Kaplan and Krumhardt 2010-scenario (KK10; [24]). KK10 is a model of Holocene land-cover change in Europe driven by population density and constrained by climate and soil characteristics. Woody vegetation cover at any time is assumed to be dependent upon the physical setting. Deforestation, in turn, is a function of the amount of cultivable land and population size, whose impact is conditioned on technological advances that improve food production (see [22] for details). Congruency between our data and the modeled time series of land-cover change lends support to the assumptions of the KK10-scenario, in particular, non-linear relationships between population density and land-use. These non-linearities have been proposed to result from land-use intensification associated with increasingly higher population densities over time [25].

According to hierarchical theory, deviations from regional fire or vegetation dynamics are expected to result from sub-region-specific factors, such as synoptic climate, soil characteristics and the local 
historical context [26]. In an effort to disentangle the regional and sub-regional-scale drivers of environmental trajectories, we (iii) divided the study area in relatively homogenous sub-regions and (iv) analyzed how fire, vegetation and anthropogenic impact at each sub-region deviated from the trends estimated for the entire study area.

\subsection{Reconstruction of Regional Trends in Fire and Vegetation during the Holocene (ca. 10,000 cal yr BP-Present)}

Charcoal and pollen data publicly available in the Global Charcoal Database (www.paleofire. org; [21,27]) and the European Pollen Database (www.europeanpollendatabase.net; [28]), respectively, were used to estimate long-term trends in fire and vegetation. Reconstructions draw on well-dated, high-resolution time series. Only the 334 sites whose chronological control and resolution are equal or higher than the median of all records in the databases are included in this study (i.e., at least one radiocarbon sample per 3000 years, and at least one charcoal sample every 56 years, or one or more pollen samples every 290 years) (Figure 1; Table S1). Past fire activity was inferred from trends in the accumulation of micro- or macro-charcoal particles in lake-sediment cores ( $<125$ and $\geq 125 \mu \mathrm{m}$; [29]). In order to reduce the influence of changes in sedimentation, non-influx data were converted to charcoal accumulation rates (CHAR Equation (1)).

$$
\mathrm{CHAR}_{(\mathrm{i})}=\operatorname{charcoal}_{(\mathrm{i})} * \text { sed. } \operatorname{rate}_{(\mathrm{i})}
$$

where charcoal $\left(\right.$ i) is the number of particles tallied in the $i^{\text {th }}$ sample and sed. rate $(i)$ is the sedimentation rate of the same sample.

CHAR were BoxCox-transformed [30] and rescaled to account for differences in particle size, laboratory techniques and analytical approach, and expressed as anomalies with respect to the Holocene range of each record. Equation (2) See [21,31,32] for further details and examples of this approach.

$$
\operatorname{tr}_{-} \mathrm{CHAR}_{(\mathrm{i})}=\left(\mathrm{CHAR}_{(\mathrm{i})}-\min (\mathrm{CHAR})\right) /(\max (\mathrm{CHAR})-\min (\mathrm{CHAR}))
$$

where tr_CHAR $($ i) corresponds to the transformed CHAR calculated for the $i$ th sample.

The reconstruction of vegetation dynamics was based on the ratio of woody to herbaceous taxa. The ratio is expected to reflect relative vegetation openness, with higher values representing closed forest, and lower ones associated with open landscapes. We also estimated the relative proportion of shrubs to total woody taxa in order to better characterize community structure.

Pollen-types commonly used as anthropogenic indicators (e.g., [33]), and present in at least $85 \%$ of the records, were factored into an anthropogenic index that served as a proxy of land-use. Specifically, the index was calculated as the sum of the minimax-transformed pollen percentages of cultivated plants identified as Avena, Hordeum, Secale cereale, Tritium, Zea mays, Cerealia, Castanea, Juglans and Olea pollen-types, and ruderal species of the genera Plantago and Rumex tallied in each sample. The proportion of the anthropogenic index to ruderals is reported and interpreted as an overall measure of the efficiency of agricultural practices.

Some of these taxa are native to Mediterranean ecosystems [34]. For this reason, changes in their abundance in the southernmost ecosystems of the study area cannot be attributed exclusively to human activities. However, given that their physiological tolerances and requirements differ, we expect the anthropogenic index to be dominated by noise in the absence of human impact. Conversely, a trend should emerge in the presence of anthropogenic activities that promote the expansion of all of these trees, herbs and grasses [35].

Following Iglesias \& Whitlock [36], we used Generalized Additive Models (GAMs) to construct regional composite records of fire, vegetation and anthropogenic impact for the Western Mediterranean and Adjacent Atlantic regions. GAMs constitute a powerful trend-detection tool that overcomes the limitations of compounded single-site interpretations, and unlike other methods employed in data synthesis, GAMs allow a specification of the link function, and do not assume linearity [37]. 
Trends in continuous, normally-distributed response variables (i.e., standardized CHAR and anthropogenic index) were modeled as smoothing functions of the concatenated data of all sites. Woody taxa percentages, which were directly derived from counts (i.e., relative quantity of pollen grains from woody species with respect to the sum of all grains in a sample), were assumed to be Poisson-distributed. For this reason, Poisson-rate GAMs with a logarithmic link between the means of the pollen counts and time were employed to ensure that the fitted values were always nonnegative. Because over-dispersion of the residuals was observed, we also assessed the performance of models that used quasi-Poisson and negative binomial distributions.

In all cases, trend estimation was based on penalized likelihood maximization. GAMs have a propensity to overfit, and careful model selection is necessary to counter this limitation. We performed this step through a comparison of Akaike's Information Criterion values (AIC; $[38,39]$ ) and an inspection of the residuals. Prior to fitting the GAMs, the time series were interpolated to their median resolution (charcoal $=36$ years $\mathrm{cm}^{-1}$; pollen $=119$ years $\mathrm{cm}^{-1}$ ) to avoid an overrepresentation of the records with higher temporal resolution. It is important to note that the relationships between pollen and vegetation, and charcoal and fire have been shown to be positive, but not necessarily linear [29,40-42]. For this reason, our reconstructions are of a qualitative nature, and a linear association between pollen or charcoal data and vegetation abundance, anthropogenic impact, or fire, is not assumed or implied.

We applied constrained cluster analysis (CONISS; [43]) to a Manhattan-distance matrix computed from the estimated regional trends in fire, vegetation and anthropogenic impact to define stages of socio-environmental development. The optimal number of stages was determined with a broken-stick model [44]. To aid in the description of the dataset, the onset of the decline of forest cover was constrained through break-point detection. The optimal number and location of break-points was estimated with the Cross-Entropy method, which is a model based on stochastic optimization [45]. The algorithm was implemented by simulating the location of break-points on sets of 200 samples $(\mathrm{M}$ $=200$ ). A subset comprising $5 \%$ of all samples was used to obtain a best performing set of sample solutions $(\rho=0.05)$.

\subsection{Reconstruction of Sub-Regional Trends in Ecosystem Dynamics during the Holocene}

Defining ecological sub-regions is a non-trivial task that involves converting a four-dimensional continuum defined by latitude, longitude, elevation and time to discrete units. To tackle this objective, we used a classification tree (i.e., a non-parametric technique employed in the partitioning of large datasets) [46] to recursively divide the space defined by the pollen samples from all sites into homogeneous vegetation zones. In particular, we modeled woody taxa pollen percentages from all samples as a function of latitude, longitude and elevation. Given that classification trees tend to overfit, the preliminary trees were cross-validated and 'pruned' to allow the generalization of the results to independent pollen datasets [47].

Spatiotemporal variability in ecosystem trajectories was assessed through a comparison of trends in charcoal, woody-to-herbaceous taxa ratios, anthropogenic indices and plant functional types (i.e., conifers, broad-leaved trees and shrubs), estimated with GAMs at each sub-region. This approach allowed the identification of periods and locations of abnormally high or low charcoal accumulation rates or pollen percentages, which are interpreted as anomalous biomass burning or woody taxa cover [48,49]. The same procedures employed in the estimation of the phases of socio-environmental development and the onset of deforestation at the regional scale were applied at each sub-region. In addition, the standardized variance of the residuals of the GAM employed in the reconstruction of the regional trend in charcoal is interpreted as a measure of the spatial variability in fire activity, with low (high) values suggesting spatially homogeneous (heterogeneous) burning.

All analyses and figures were made using R-programming version 3.0.2 [50] with packages AID 1.4 [51], akima 0.5-11 [52], alr3 [53], breakpoint [45], dplyr 0.4.3 [54], ggplot2 [55], mgcv 1.7-29 [37], rioja [56]; tree 1.0-35 [57], and corresponding dependencies. 


\section{Results and Discussion}

\subsection{Regional Trends in Ecosystem Dynamics during the Holocene}

Multivariate analysis of the charcoal, pollen and anthropogenic index time series (i.e., CONISS) allowed the identification of four stages in the development of socio-environmental systems (Table 1; Figure 2):

Table 1. Generalized Additive Models (GAMs) applied to the charcoal and pollen data to estimate trends in fire and woody taxa abundance anthropogenic impact, respectively.

\begin{tabular}{|c|c|c|c|}
\hline Model & Family & Dev. Expl. * & $\delta \mathrm{AIC}$ \\
\hline \multicolumn{4}{|l|}{$\begin{array}{l}\text { Western Mediterranean and Adjacent } \\
\text { Atlantic Regions }\end{array}$} \\
\hline $\mathrm{Ch}_{\mathrm{t}}=\alpha+\mathrm{f}\left(\right.$ Time $\left._{\mathrm{i}}\right)+$ Site $_{\mathrm{i}}+\varepsilon_{\mathrm{i}}$ & Gaussian & $66.4 \%$ & 101 \\
\hline $\begin{array}{c}W_{t}=\alpha+f\left(\text { Time }_{i}\right)+\text { Site }_{i}+ \\
\log \left(\text { Terrestrial pollen sum }{ }^{-1}\right)_{i}+\varepsilon_{i}\end{array}$ & Neg. binom. & $39.8 \%$ & 7001 \\
\hline $\begin{array}{c}\mathrm{AI}_{\mathrm{t}}=\alpha+\mathrm{f}\left(\text { Time }_{\mathrm{i}}\right)+\text { Site }_{\mathrm{i}}+\varepsilon_{\mathrm{i}} \\
\text { Temperate Western Europe }\end{array}$ & Gaussian & $58.8 \%$ & 1779 \\
\hline $\mathrm{Ch}_{\mathrm{t}}=\alpha+\mathrm{f}\left(\right.$ Time $\left._{\mathrm{i}}\right)+$ Site $_{\mathrm{i}}+\varepsilon_{\mathrm{i}}$ & Gaussian & $36.9 \%$ & 3 \\
\hline $\begin{array}{c}W_{t}=\alpha+f\left(\text { Time }_{i}\right)+\text { Site }_{i}+ \\
\log \left(\text { Terrestrial pollen sum }^{-1}\right)_{j}+\varepsilon_{i}\end{array}$ & Quasipoisson & $81.2 \%$ & NA \\
\hline $\begin{aligned} \mathrm{AI}_{\mathrm{t}}= & \alpha+\mathrm{f}\left(\text { Time }_{\mathrm{i}}\right)+\text { Site }_{\mathrm{i}}+\varepsilon_{\mathrm{i}} \\
& \text { Alpine subregion }\end{aligned}$ & Gaussian & $59.8 \%$ & 1914 \\
\hline $\mathrm{Ch}_{\mathrm{t}}=\alpha+\mathrm{f}\left(\right.$ Time $\left._{\mathrm{i}}\right)+$ Site $_{\mathrm{i}}+\varepsilon_{\mathrm{i}}$ & Gaussian & $42.5 \%$ & 36 \\
\hline $\begin{array}{c}\mathrm{W}_{\mathrm{t}}=\alpha+\mathrm{f}\left(\text { Time }_{\mathrm{i}}\right)+\text { Site }_{\mathrm{i}}+ \\
\log \left(\text { Terrestrial pollen sum }{ }^{-1}\right)_{\mathrm{i}}+\varepsilon_{\mathrm{i}}\end{array}$ & Poisson & $82.9 \%$ & 13,381 \\
\hline $\begin{array}{l}\mathrm{AI}_{\mathrm{t}}=\alpha+\mathrm{f}\left(\text { Time }_{\mathrm{i}}\right)+\text { Site }_{\mathrm{i}}+\varepsilon_{\mathrm{i}} \\
\text { Northern Mediterranean }\end{array}$ & Gaussian & $59.7 \%$ & 999 \\
\hline $\mathrm{Ch}_{\mathrm{t}}=\alpha+\mathrm{f}\left(\right.$ Time $\left._{\mathrm{i}}\right)+$ Site $_{\mathrm{i}}+\varepsilon_{\mathrm{i}}$ & Gaussian & $47.1 \%$ & 55 \\
\hline $\begin{array}{c}W_{t}=\alpha+f\left(\text { Time }_{i}\right)+\text { Site }_{i}+ \\
\log \left(\text { Terrestrial pollen sum }{ }^{-1}\right)_{i}+\varepsilon_{i}\end{array}$ & Quasipoisson & $78.3 \%$ & NA \\
\hline $\begin{array}{l}\mathrm{AI}_{\mathrm{t}}=\alpha+\mathrm{f}\left(\text { Time }_{\mathrm{i}}\right)+\text { Site }_{\mathrm{i}}+\varepsilon_{\mathrm{i}} \\
\text { Southern Mediterranean }\end{array}$ & Gaussian & $45.0 \%$ & 775 \\
\hline $\mathrm{Ch}_{\mathrm{t}}=\alpha+\mathrm{f}\left(\right.$ Time $\left._{\mathrm{i}}\right)+$ Site $_{\mathrm{i}}+\varepsilon_{\mathrm{i}}$ & Gaussian & $53.1 \%$ & 60 \\
\hline $\begin{array}{c}W_{t}=\alpha+f\left(\text { Time }_{i}\right)+\text { Site }_{i}+ \\
\log \left(\text { Terrestrial pollen sum }{ }^{-1}\right)_{i}+\varepsilon_{i}\end{array}$ & Poisson & $52.0 \%$ & 35,171 \\
\hline $\mathrm{AI}_{\mathrm{t}}=\alpha+\mathrm{f}\left(\right.$ Time $\left._{\mathrm{i}}\right)+$ Site $_{\mathrm{i}}+\varepsilon_{\mathrm{i}}$ & Gaussian & $40.8 \%$ & 96 \\
\hline
\end{tabular}

Where charcoal $(\mathrm{Ch})$, woody taxa $(\mathrm{W})$ and the anthropogenic index (AI) were modeled as smoothing functions of the concatenated time data of all sites $\left[\mathrm{f}\left(\mathrm{Time}_{\mathrm{i}}\right)\right]$ and the nominal variable Site $\mathrm{i}_{\mathrm{i}} \alpha$ is the intercept for the baseline site, $\log \left(\text { Terrestrial pollen sum }{ }^{-1}\right)_{\mathrm{i}}$ and $\log (\text { Accumulation rate })_{\mathrm{i}}$ are the offsets of the models, and $\varepsilon_{\mathrm{i}}$ is the $i^{\text {th }}$ residual. * Dev. expl. = Deviance explained. 


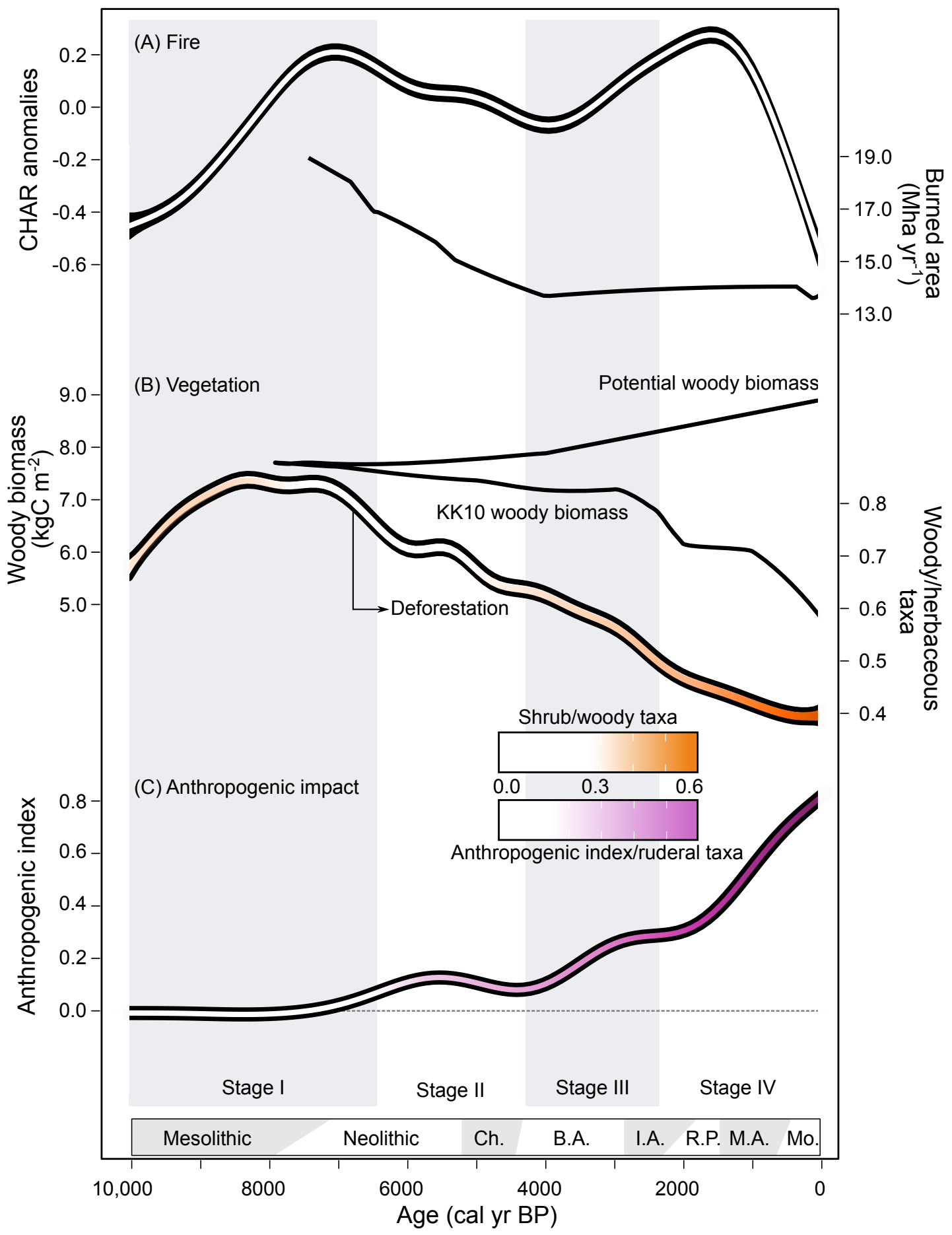

Figure 2. Holocene trends in fire, vegetation and anthropogenic impact in the Western Mediterranean and Adjacent Atlantic Regions (WMAAR). (A) Regional biomass burning, as estimated by a Generalized Additive Model (GAM) applied to the charcoal data from the entire Western Mediterranean and Adjacent Atlantic Regions (this study), and modeled area burned [5]. (B) Vegetation openness inferred from modeled potential woody biomass [5], biomass under the KK10 scenario [25] and regional woody-to-herbaceous pollen taxa (this study). The relative proportion of shrubs-to-woody taxa pollen is shown in orange. The arrow indicates the onset of pronounced forest loss identified through the Cross-Entropy method for break-point detection. (C) Anthropogenic index as a function of time (this study). The pink shading represents the total anthropogenic index-to-ruderal taxa ratio. In all cases, the black shading depicts $95 \%$ confidence intervals for the estimated trends. 


\subsubsection{Stage I (>ca. 6500 cal yr BP): Hunting-Gathering in Densely Forested Landscapes}

This socio-environmental system is coeval with the end of the Mesolithic and characterized by very high levels of biomass burning, abundant woody vegetation (predominantly conifers and broad-leaved trees), and negligible evidence of anthropogenic impact on the landscape (as inferred from an anthropogenic index statistically equal to zero). Between ca. 10,000 and $7000 \mathrm{cal} \mathrm{yr} \mathrm{BP,} \mathrm{summer}$ insolation was $\sim 7 \%$ higher than at present, and winter values were $\sim 4 \%$ lower [58]. Paleoclimate models and multi-proxy reconstructions suggest that elevated annual insolation at the time was associated with pronounced seasonality [59], higher Mediterranean Sea surface temperatures [60], 2-2.5 ${ }^{\circ} \mathrm{C}$ warmer summers, and a more relaxed pole-to-Equator pressure gradient than at present $[61,62]$. This climatic configuration likely led to a northward shift of the North Atlantic low- and high-pressure systems and Intertropical convergence zone (ITZD). The blocking effects of the North Atlantic high-pressure system on atmospheric circulation would have prevented Atlantic moisture from reaching latitudes north of $40^{\circ} \mathrm{N}$, and would thus have resulted in drier-than-present environments throughout most of the region [63,64]. Conversely, wetter-than-today conditions punctuated by periods of drought [65] would have been brought about by cyclic Atlantic flow south of this latitude ([62] and references therein).

Matching trends in biomass burning and tree abundance inferred from climate-driven models and proxy data suggest that fires and extensive forest cover prior to $7000 \mathrm{cal} \mathrm{yr} \mathrm{BP}$ at the regional scale can be explained by the long, warm growing seasons prevailing in southwestern Europe (with the exception of southeastern Iberia and southwestern Italy; Figure 2). Pronounced seasonal and inter-annual precipitation variability [66,67] likely led to frequent floods [68]. Additionally, cyclical oscillations in moisture availability would also have favored fire spread by allowing fuel accumulation during humid periods and fuel desiccation in under drier conditions [69]. Hunter-gatherers may have operated synergistically with climate to maintain the fire regime and improve or perpetuate foraging conditions within forest patches [70]. Although our data show no evidence of changes in the overall structure of the vegetation that would suggest large-scale, persistent anthropogenic impact (i.e., quasi-stationary woody-to-herbaceous taxa ratio and anthropogenic index equal to zero), they do not rule out small-scale burning. This management strategy could have created complex vegetation patterns and increased the density and predictability of resources [71]. In time, each burned patch would have returned to its pre-disturbance state, resulting in no net change in vegetation composition [72].

\subsubsection{Stage II (ca. $6500-4200$ cal yr BP): Extensive Land-Use of Semi-Open Forests}

The Mesolithic-to-Neolithic transition featured a progression from warm growing seasons to overall cooler, relatively humid climates $[64,68,73]$. Regionally, a decline in biomass burning was accompanied by pronounced forest loss. Divergent trends in potential woody biomass and the reconstructed opening of the landscape, in addition to increasing evidence of anthropogenic activity (Figure 2), suggest that the effects of resource management prevailed over those of climate on ecosystem dynamics. In Iberia, for example, spatial variability at the time has been associated with complex patterns of vegetation change that cannot be solely explained by differences in physical setting $[74,75]$. Carrión et al. [76] attribute this complex mosaic to anthropogenic impact, whose intensity would have been heterogeneous, and its effects, site-dependent [75].

Forest clearing by early peoples has been registered in many parts of the world, but always with significant manipulation of the fire regime (e.g., [77]). Our data, nonetheless, indicate that in the WMAAR, rapid, widespread deforestation occurred prior to the invention of metallic tools and without large-scale biomass burning, whose long-term trend prior to ca. $4000 \mathrm{yr}$ BP can be attributed to climate (Figure 2). Early studies by Iversen [78] conclude that even though cutting branches and seedlings with stone axes is relatively easy, felling older trees can be a strenuous activity. It is thus highly unlikely that early farmers used this method to clear mature forests. Instead, it is more plausible that they took advantage of naturally-occurring disturbances such as climate variability and fires, and managed non-forested patches to maintain high-productivity, early-successional ecosystems. 
Opportunistic exploitation of the environment would not have necessarily precluded the use of frequent, relatively small fires to create or maintain clearings that aided in the expansion of agriculture. Anthropogenic fires employed as a management tool usually produce fine-scale vegetation patterns that attenuate the severity of the fire regime at larger spatial scales [70]. In most cases, charcoal time series do not have the temporal or spatial resolution to distinguish several frequent, small fires from a few large ones [79]. For this reason, it is possible that targeted low-severity burning was involved in the pronounced decline of tree populations (e.g., [80,81]).

Regardless of the mechanisms driving the reconstructed structural change in vegetation, rising anthropogenic index values suggest that deliberate propagation of species of nutritional value, the inadvertent spread of weeds, and possibly grazing, were significant at the regional-scale after ca. $7000 \mathrm{cal}$ yr BP. The development of a more diversified economy, increasingly sedentary life-styles and rapidly growing human populations [82,83], would have resulted in a new form of frequent and extensive disturbance that probably led to profound and persistent changes in the landscape that cannot be explained by climate alone $[1,84-87]$.

\subsubsection{Stage III (ca. $4200-2400$ cal yr BP): Expansion of Anthroposystems in More Open Landscapes}

The Late Holocene is characterized by spatially-variable climate conditions across the region [88-90]. Decreasing woody-taxa pollen percentages at the time are consistent with sustained deforestation, which was associated with shrub encroachment and a rise in biomass burning. Contrasting trends in reconstructed and potential vegetation, as well as in charcoal and modeled area burned (Figure 2), point to a remarkable decoupling of ecosystem dynamics from climate.

Although crop rotation and the use of dung as fertilizer would have increased crop yields, continuous expansion of the agricultural frontier was still necessary [91]. To this end, conversion of forested lands into areas suitable for crops and pastures for cattle, sheep, goats and pigs would have been performed mainly with the use of fire [72]. It is therefore possible that, through targeted and probably frequent ignitions, humans extended the climatically short and humid fire season, and emerged as a large-scale forcing of fire. Additional deforestation could have been brought about by wood extraction and pollution associated with the rapid development and intensification of metallurgic industries, but the long-term impact of these activities is still in debate (e.g., [92]).

The human footprint on the landscape became especially pronounced during the late Bronze Age and Iron Age (ca. 3200-2400 cal yr BP), and was likely driven by the need of larger human populations to sustain their rising energy demands ([72]). Increasingly larger proportions of taxa of nutritional value with respect to ruderals in the anthropogenic index suggest that this period represents a transition to more intense and efficient agriculture practices (Figure 2).

\subsubsection{Stage IV (ca. 2400 cal yr BP-Present): Intensive Land-Use and Urban Extractive Industries}

The last two millennia display progressive but slower-than-before deforestation and the highest rates of human impact in the Holocene. Biomass burning peaked during the Roman Period (ca. 2000 cal yr BP) and declined afterwards (Figure 2). It is likely that, as soils degraded and lost productivity, human populations continued to grow and social structures changed, fire was continuously used to expand the surface of arable lands to the detriment of forests. This expansion was in part possible due to the adoption of technological innovations. The wheeled plow and moldboard, for instance, are thought to have facilitated the use of heavy, moist and productive soils that were previously very difficult to cultivate [93].

During the Modern period, biomass burning declined, and deforestation rates slowed at the regional scale, possibly because of the combined effects of long-term anthropogenic impact, increased food-production efficiency and a change in socio-economic structures. Millennia of progressive forest opening and landscape fragmentation would have significantly reduced the availability and continuity of fuels, limiting fire spread and intensity $[59,81,94,95]$. In addition, the maintenance of agro-pastoral systems would have been less dependent upon fire, thanks to the adoption of improved felling axes [77], 
and higher crop yields were plausibly achieved after the development and spread of efficient tools, such as iron scythes and nailed horseshoes.

Emerging land management technologies likely permitted decreasing land-use per capita, slowing the expansion of arable lands, despite rapidly growing human populations [2]. In addition, the collapse of the Roman state brought about large changes in institutions, transport, communication, food supply and taxation [96]. The new organizational regime led to a shift from a state-stimulated, large-scale production of grain, oil and wine (i.e., the Mediterranean Triad) with high levels of surplus allocated towards exchange and commerce, to a less-specialized system of mixed farming, arboriculture, animal husbandry and pastures [97].

\subsection{The Role of Climate and Humans in Driving Regional Ecosystem Dynamics}

Comparison of pollen-based deforestation reconstructions and simulated land-cover changes lends support to the assumptions of the KK10-scenario; i.e., a shift in socio-environmental systems governed by a Malthusian representation of population growth prior to ca. $4000 \mathrm{cal} \mathrm{yr} \mathrm{BP,} \mathrm{to} \mathrm{agricultural}$ intensification afterwards [25]. Congruent trends in simulated and reconstructed biomass therefore suggest that the extent of land used by hunter-gatherers would have been proportional to population size [98], and ecosystem dynamics were largely driven by climate. As populations grew during the Neolithic, land-use per capita declined, possibly as a result of changes in production traditions and technological innovations, leading to more complex and efficient resource exploitation [99].

Although vegetation reconstructions and models agree on the overall deforestation trend, they differ in the rates at which it occurred. The pollen-based reconstruction suggests a steady decline in woody biomass between ca. 7000 and $3000 \mathrm{cal} \mathrm{yr} \mathrm{BP,} \mathrm{followed} \mathrm{by} \mathrm{a} \mathrm{millennium} \mathrm{of} \mathrm{rapid} \mathrm{loss} \mathrm{of} \mathrm{trees,}$ and slower deforestation rates coupled with shrub encroachment in the last ca. 2000 years. Conversely, the KK10-derived scenario indicates relatively slow forest loss prior to ca. 3000 , and very high rates thereafter, with the exception of around a 500-year period of stability centered at $1000 \mathrm{cal} \mathrm{yr} \mathrm{BP.}$

Uncertainty propagation in the merging of datasets (i.e., uncertainties inherent to the reconstruction and interpretation of environmental conditions, population size and timing of events) could explain the discrepancy. Alternatively, it is also possible that some of the underlying assumptions of the KK10 scenario are not likely given the empirical data. For example, the simulation builds upon the idea that the carrying capacity of the land (i.e., the population density it can support) changes only as a function of human labor and technology. Considering the pronounced shifts in climate inferred for the Holocene, fertility and resource availability possibly varied over time, even without human intervention. Additionally, the definition of 'resource' probably changed as culture, technology and religion were transformed, with the extraction of metals being a clear example. This variability in both environmental conditions and the human perception of the landscape, may be reflected in land-use per capita.

\subsection{Sub-Regional Trends in Ecosystem Dynamics during the Holocene}

A classification tree allowed the partition of the study area into discrete sub-units with relatively homogenous palynological characteristics. After pruning the tree (residual mean deviance $=354.9$; residual mean $=0$; residual standard deviation $=12.4$ ), four sub-regions were identified (Figure 1). Temperate western Europe (TwE; lat. $>41.76$, elev. $<1200 \mathrm{~m}$ ) mainly comprises modern temperate broadleaf and mixed forests. The Alpine sub-region (Al.; lat. $>41.76$, elev. $>1200 \mathrm{~m}$ ) overlaps with high-elevation conifer forests, grasslands and meadows of the Alps. Finally, Northern Mediterranean (NM; elev. > $108 \mathrm{~m}$ and lat. < 41.76) and Southern Mediterranean (SM; elev. < $108 \mathrm{~m}$ ) correspond to present-day Mediterranean forests, woodlands and shrublands. Inspection of charcoal records, woody-to-herbaceous taxa ratios and anthropogenic indices, reveals that all sub-regions featured sustained an increase in human impact and forest loss over time (Figures 3-6). 


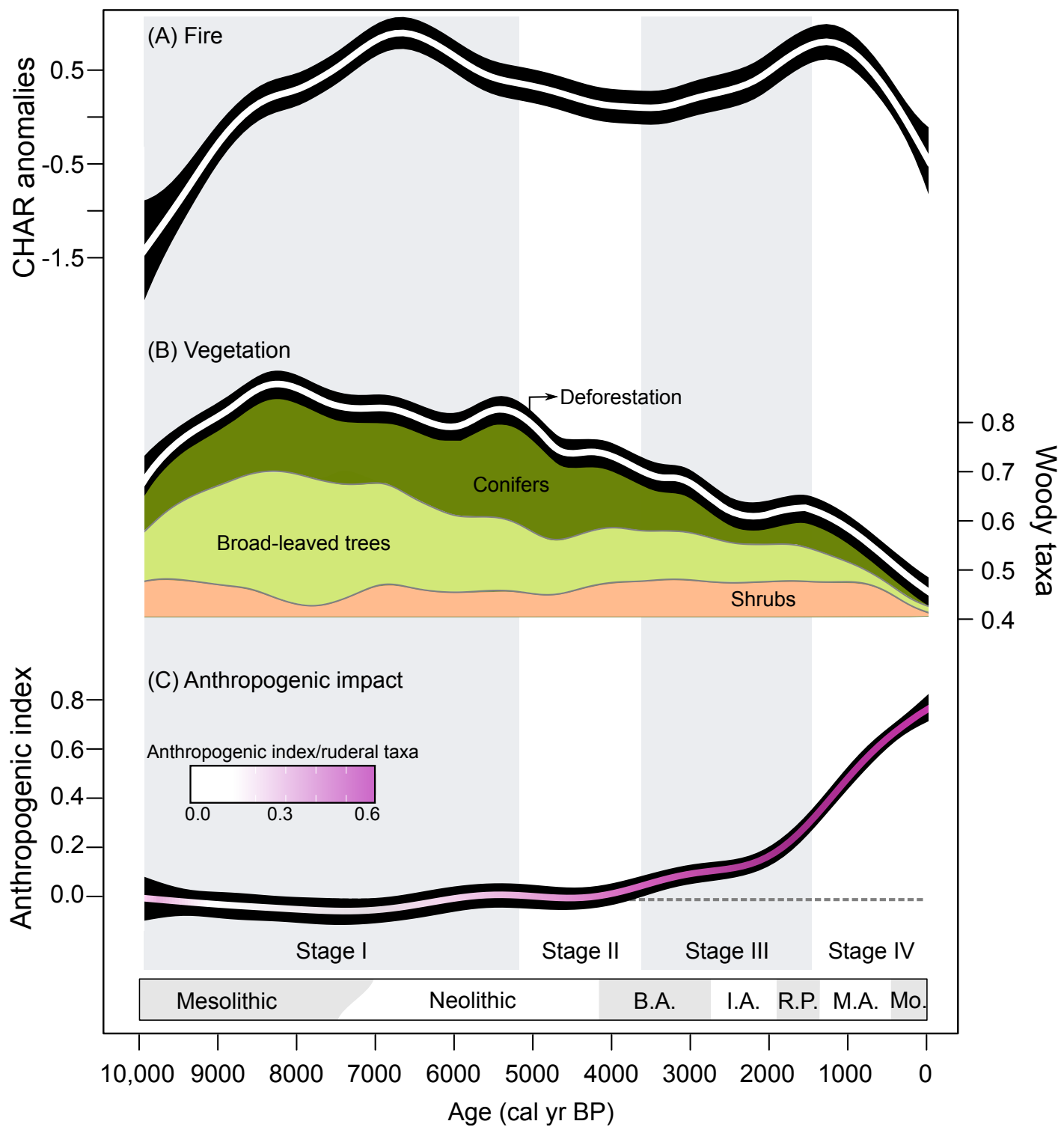

Figure 3. Holocene trends in fire, vegetation and anthropogenic impact in Temperate western Europe. (A) Regional biomass burning as estimated by a GAM applied to the charcoal data from the sub-region. (B) Vegetation openness inferred from woody-to-herbaceous pollen taxa. The relative proportion of conifers, broad-leaved trees and shrubs is shown. (C) Anthropogenic index as a function of time. The pink shading represents the total anthropogenic index-to-ruderal taxa ratio. The arrow shows the onset of pronounced deforestation depicted in Figure 7 . In all cases, the black shading depicts $95 \%$ confidence intervals for the estimated trends. 


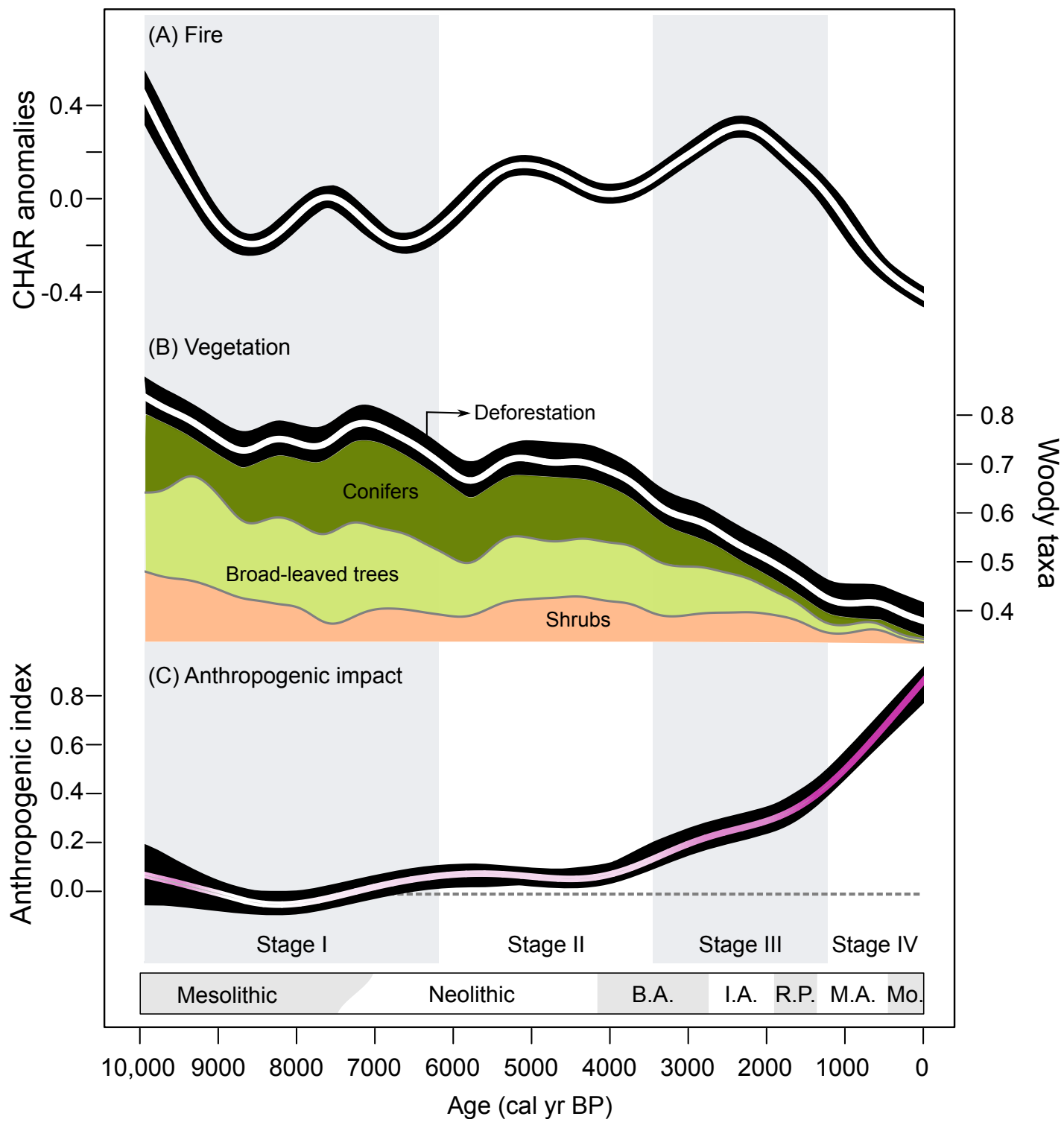

Figure 4. Holocene trends in fire, vegetation and anthropogenic impact in the Alpine sub-region. (A) Regional biomass burning as estimated by a GAM applied to the charcoal data from the sub-region (B) Vegetation openness inferred from woody-to-herbaceous pollen taxa. The relative proportion of conifers, broad-leaved trees and shrubs is shown. (C) Anthropogenic index as a function of time. The pink shading represents the total anthropogenic index-to-ruderal taxa ratio. The arrow shows the onset of pronounced deforestation depicted in Figure 7 . In all cases, the black shading depicts $95 \%$ confidence intervals for the estimated trends. 


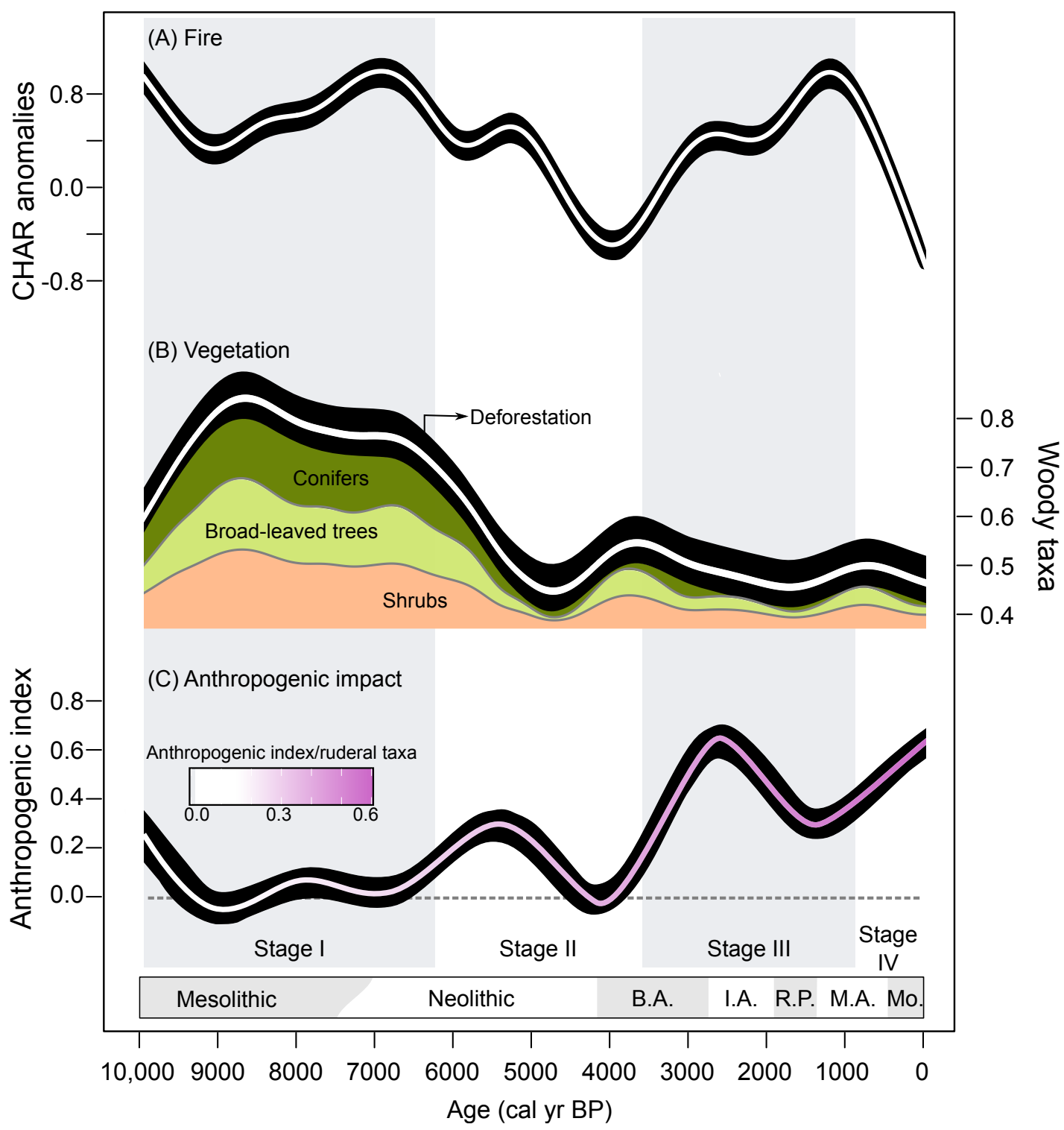

Figure 5. Holocene trends in fire, vegetation and anthropogenic impact in the Northern Mediterranean. (A) Regional biomass burning as estimated by a GAM applied to the charcoal data from the sub-region (B) Vegetation openness inferred from woody-to-herbaceous pollen taxa. The relative proportion of conifers, broad-leaved trees and shrubs is shown. (C) Anthropogenic index as a function of time. The pink shading represents the total anthropogenic index-to-ruderal taxa ratio. The arrow shows the onset of pronounced deforestation depicted in Figure 7 . In all cases, the black shading depicts $95 \%$ confidence intervals for the estimated trends. 


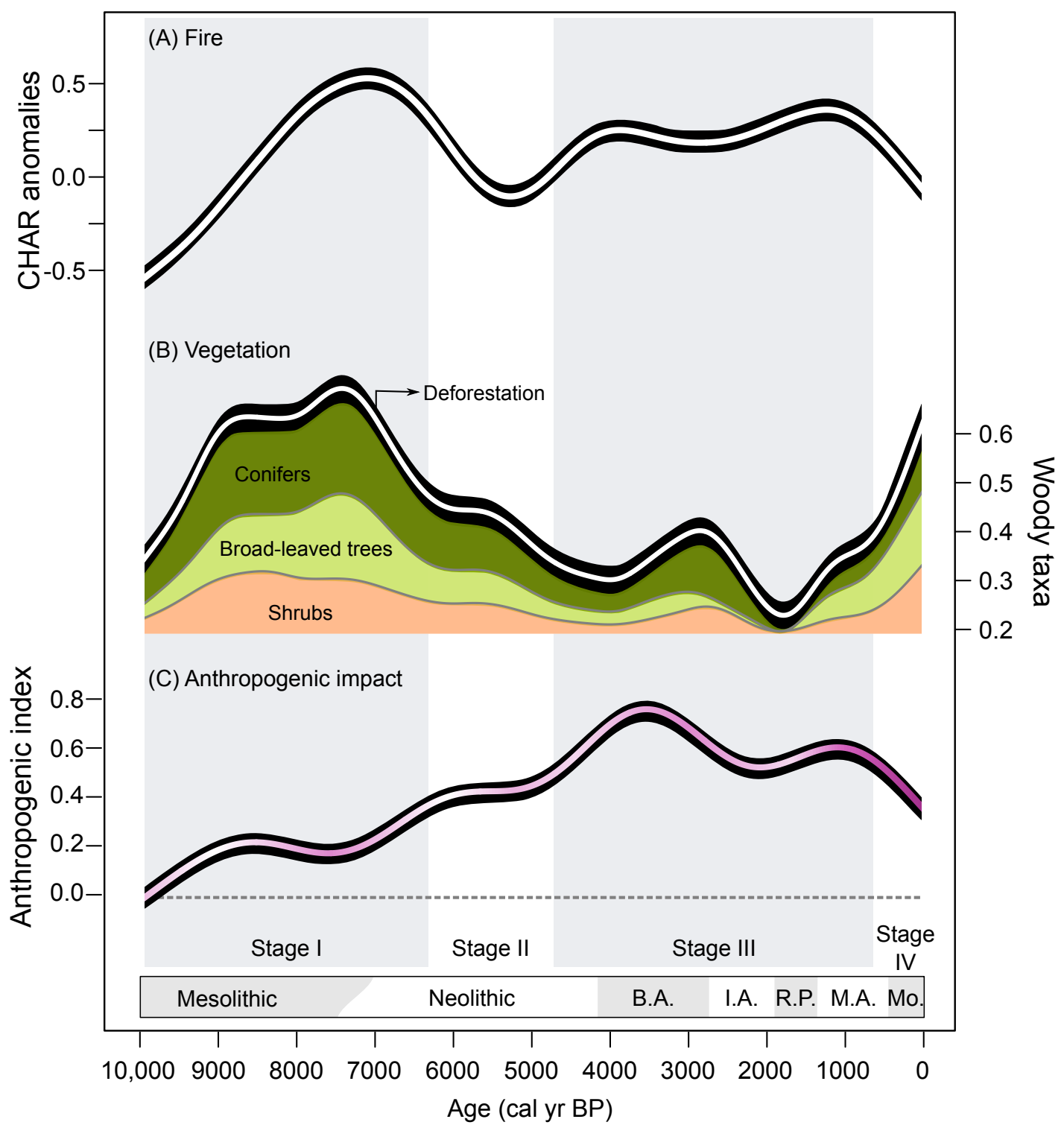

Figure 6. Holocene trends in fire, vegetation and anthropogenic impact in the Southern Mediterranean. (A) Regional biomass burning as estimated by a GAM applied to the charcoal data from the sub-region (B) Vegetation openness inferred from woody-to-herbaceous pollen taxa. The relative proportion of conifers, broad-leaved trees and shrubs is shown. (C) Anthropogenic index as a function of time. The pink shading represents the total anthropogenic index-to-ruderal taxa ratio. The arrow shows the onset of pronounced deforestation depicted in Figure 7. In all cases, the black shading depicts $95 \%$ confidence intervals for the estimated trends.

At the regional-scale, comparison of modeled and reconstructed trends in area burned point to a progressive decoupling between climate and fire activity after ca. $4000 \mathrm{cal} \mathrm{yr} \mathrm{BP.} \mathrm{Conversely,} \mathrm{at} \mathrm{the}$ sub-regional scale, charcoal trends show that fire activity, which was spatially homogeneous prior to ca. $7000 \mathrm{cal}$ yr BP, became highly variable between ca. 7000 and $4000 \mathrm{cal} \mathrm{yr} \mathrm{BP,} \mathrm{and} \mathrm{pronouncedly}$ more uniform thereafter (Figure 7). In Temperate western Europe (TwE) and the Northern (NM) and Southern Mediterranean (SM) biomass, burning increased monotonically until ca. $7000 \mathrm{cal}$ yr BP and then decreased to reach local minima between ca. 5500 and 4000 cal yr BP (Figures 3-5). The inverse trend was observed in the Alpine sub-region (Figure 6). 
(A)

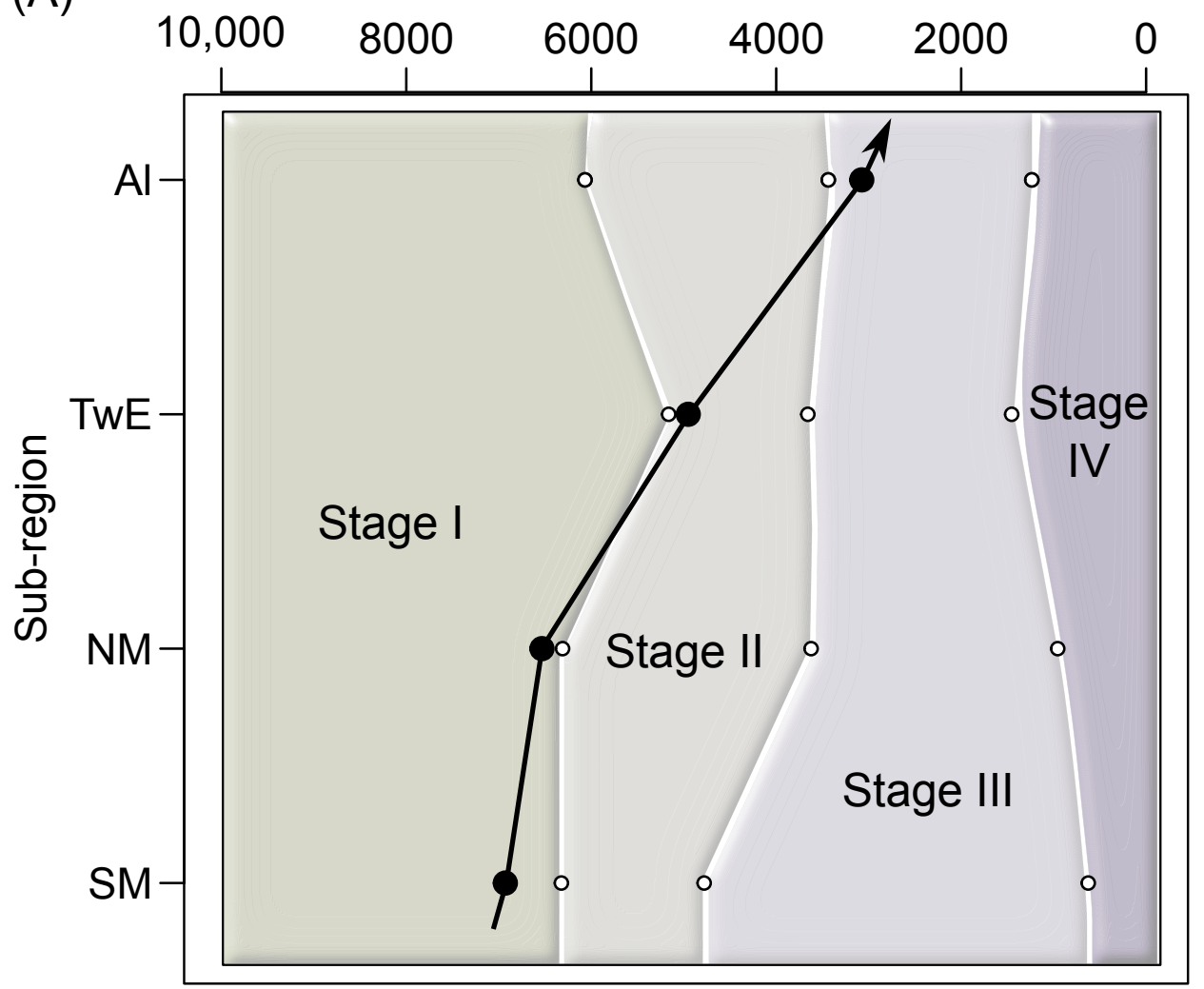

(B)

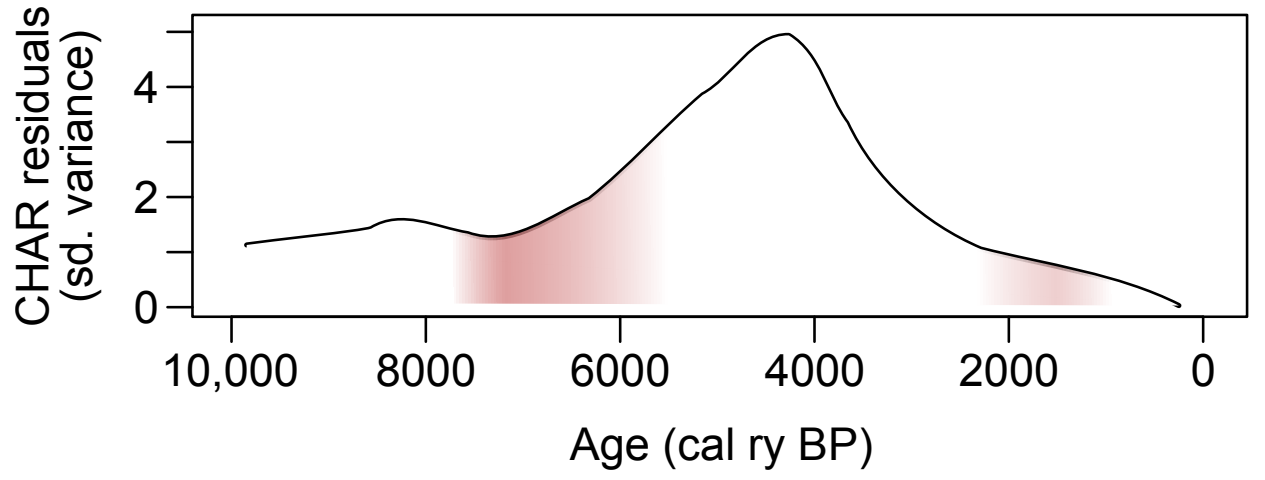

Figure 7. (A) Stages of socio-environmental development. The black line depicts the onset of pronounced forest loss identified at each sub-region through the Cross-Entropy method for break-point detection. Note the south-to-north time-transgressive pattern of deforestation. (B) Standardized variance of the residuals of the GAM employed in the detection of temporal trends in charcoal. The values are interpreted as a measure of spatial variability in fire activity, with low (high) values suggesting homogeneous (heterogeneous) burning.

Warm, dry summers and pronounced seasonal precipitation variability before ca. $7000 \mathrm{cal}$ yr BP ([67] were associated with long fire seasons and abundant dry fuel at lower elevations [34,85,100-105]. These conditions would have increased the probability of large fires and explain the peak in burning throughout a large portion of the region [5].

A contrasting pattern in biomass burning inferred for the Alpine sub-region can be attributed to the direct effects of elevation on synoptic climate and its indirect consequences on ecosystem processes. By $8700 \mathrm{cal}$ yr BP, winter precipitation was relatively abundant in the mountainous areas of central Europe, and triggered peat accumulation in the Jura mountains [89] and a shift from pronounced 
retrogradation (i.e., recession of river deltas associated with low sediment input) to slow transgression (i.e., increased sediment input resulting from higher up-valley erosion) in the Maritime Alps [106]. Consequently, soils would have been either covered by snow or humid during the spring/early summer months.

Generalized lowering of the upper tree line was also registered at the time $[69,107,108]$. The lack of fuel continuity $[59,109]$ coupled with abundant moisture, would have precluded fire ignition and spread, despite high temperatures $[5,84,110]$. Paleoenvironmental data thus point to a strong top-down control of climate on environmental dynamics, modulated by vegetation-fire linkages characteristic of each sub-region.

At the regional-scale, the earliest signal of anthropogenic impact on ecosystem structure is provided by the departure of the reconstructed trend in woody biomass from the potential woody biomass modeled for the area. Comparison of the onset of forest degradation at each sub-region shows that it started as early as ca. $7000 \mathrm{cal} \mathrm{yr} \mathrm{BP}$ in the Southern Mediterranean, and not until ca. $5300 \mathrm{cal} \mathrm{yr} \mathrm{BP}$ in the north of the region (Figure 7). The emerging time-transgressive pattern of deforestation matches models of Neolithic incursions and population growth $[3,6,82]$, and is coupled with a coeval rise in the anthropogenic index in all sub-regions (Figures 3-6).

Woody pollen data suggest that, while Temperate western Europe (TwE) and the Alpine sub-region (Al) featured relatively slow deforestation rates (Figures 3 and 4), forest loss was very rapid in the Northern (NM) and Southern Mediterranean (SM) sub-regions (Figures 5 and 6). This contrast could be due to differential land-use intensities, ecological feedbacks and/or synoptic climate. Historiographic information from the Iberian Peninsula and Northern Africa, for instance, reveals that pastoralism and agriculture rapidly replaced the coastal economies of Mesolithic populations after ca. $7500 \mathrm{cal}$ yr BP [111]. This rapid transition, which is attributed to a crisis in the subsistence system driven by decreased marine productivity and drier conditions along the coast [112], had no analogs in the TwE or Al sub-regions.

In addition, regeneration in forests in NM and SM would have been more difficult than in more humid, deciduous forests to the north [113]. Neighborhood analysis of modern Quercus woodlands suggests that the presence of trees positively affects the emergence of seedlings [114]. Climate and deforestation may have therefore altered vegetation trajectories through neighbor-specific impacts on the recruitment of arboreal species, indirectly favoring the expansion of open vegetation.

The last ca. 4000 years are characterized by cooler summers and increasingly higher lake levels in Temperate western Europe, the Alpine sub-region and the Northern Mediterranean [88-90]. In mountainous areas, lower temperatures and abundant moisture promoted neoglaciation [115]. Conversely, the Southern Mediterranean featured the onset of an aridification process that has lasted until the present [116-121]. Despite different trends in climate, decreasing woody taxa pollen percentages are consistent with sustained and widespread deforestation, and associated with shrub encroachment and spatially homogeneous fire activity (Figure 7). In addition, similar patterns of landscape evolution, including shrub encroachment, increased erosion [115,122], peat humification [89], soil impoverishment [94], floods, allochthonous input to lakes [68] and altered aquatic biological interactions [123], have been registered in all sub-regions. The decoupling of ecosystem processes from large-scale forcing during the Neolithic-to-Bronze Age transition suggests that land management mitigated the effects of climate, fuel and topography.

Although human impact and ecosystem trajectories in recent millennia were similar across sub-regions, they were not identical. For example, deforestation in Temperate western Europe and the Alpine sub-region was steady, and mainly characterized by the loss of conifers, while the abundance of anthropogenic indicators rose uninterruptedly (Figs. 3 and 4). The decline in tree populations was particularly pronounced in the Alpine sub-region, and has been correlated with the local extinction of trees such as Abies and Taxus [124], increased landslide activity at the Schwartsee (Switzerland) and erosion at Lake d'Annecy (France), and in all cases is attributed to human impact ([115,125], respectively). It is possible, however, that the advance of glaciers led to changes in stream piracy, 
altering the routing of water and sediment in mountainous areas. These conditions may have led to a redistribution of effective moisture that amplified the impact of human-set fires and grazing upon vegetation.

Further south, rates of land opening were slower, non-monotonic and accompanied by high fire activity (Figures 5 and 6). Aridification in the Northern and Southern Mediterranean is likely to have promoted (or at least facilitated) the shrinkage of forests and the spread of fire. However, anthropogenic indicators show a similar trend to that of charcoal until ca. $1500 \mathrm{cal} \mathrm{yr} \mathrm{BP}$ in both sub-regions, attesting to the likely use of fire for agricultural purposes (e.g., [85,126]) as well as to periods of land-use intensification alternating with times of de-intensification (e.g., [34,96]).

\section{Conclusions}

The Western Mediterranean and Adjacent Atlantic Regions has been continuously inhabited since the beginning of the Holocene. Paleoenvironmental data reveal a sustained increase in anthropogenic impact during this period, as indicated by pronounced non-climate-driven deforestation after ca. 7000 cal yr BP, and rising evidence of crops and ruderal species.

Further support to the role of humans in altering ecosystem dynamics comes from the reconstructed decoupling of vegetation from climate, which displayed an overall south-to-north time-transgressive pattern consistent with current models of population expansion in Europe and northern Africa [6,34]. Our results thus point to a shift from a strong top-down control of climate to a progressively larger anthropic signal on environmental dynamics.

As human impact increased, so did the use of fire. Remarkably uniform biomass burning across the region after ca. 4000 cal yr BP cannot be explained by climate alone. This large-scale homogeneity in fire activity suggests that land management at the time was extensive and efficient enough to override the effects of climate, fuel and topography. The long-term history of the Western Mediterranean and Adjacent Atlantic Regions thus reveals that the complex mosaic of landscapes characteristic of the region emerged from non-linear, evolving interactions among biophysical and social processes that have operated across scales for millennia.

Supplementary Materials: The following are available online at http://www.mdpi.com/2571-6255/2/4/53/s1, Table S1: Paleoenvironmental records used in this study.

Author Contributions: Conceptualization, V.I., B.V. and I.J.-B.; Methodology, V.I.; Formal Analysis, V.I.; Investigation, V.I., B.V. and I.J.-B.; Data Curation, V.I.; Writing-Original Draft Preparation, V.I.; Writing-Review \& Editing, V.I., B.V. and I.J.-B.; Visualization, V.I.; Supervision, B.V.; Project Administration, B.V.; Funding Acquisition, B.V.

Funding: This research was funded by the CNRS PaléoMEx-MISTRALS program, Région Bourgogne Franche-Comté through MSHE C.-N. Ledoux, Project of excellence GDRI TSEPE, and Earth Lab through the University of Colorado-Boulder's Grand Challenge Initiative.

Acknowledgments: We thank the contributors of the European Pollen Database and Global Charcoal Database for making their records publicly available and Laurie Stahle for her valuable comments.

Conflicts of Interest: The authors declare no conflict of interest. The funders had no role in the design of the study; in the collection, analyses, or interpretation of data; in the writing of the manuscript, or in the decision to publish the results.

\section{References}

1. Ellis, E.C.; Kaplan, J.O.; Fuller, D.Q.; Vavrus, S.; Goldewijk, K.K.; Verburg, H.P. Used planet: A global history. Proc. Natl. Acad. Sci. USA 2013, 110, 7978-7985. [CrossRef] [PubMed]

2. Ruddiman, W.F.; Ellis, E.C. Effect of per-capita land use changes on Holocene forest clearance and $\mathrm{CO}_{2}$ emissions. Quat. Sci. Rev. 2009, 28, 3011-3015. [CrossRef]

3. Bocquet-Appel, J.P.; Naji, S.; Vander Linden, M.; Kozlowski, J.K. Detection of diffusion and contact zones of early farming in Europe from the space-time distribution of ${ }^{14} \mathrm{C}$ dates. J. Archaeol. Sci. 2009, 36, 807-820. [CrossRef] 
4. Roberts, N.; Fyfe, R.M.; Woodbridge, J.; Gaillard, M.-J.; Davis, B.A.S.; Kaplan, J.; Marquer, L.; Mazier, F.; Nielsen, A.B.; Sugita, S.; et al. Europe's lost forests: A pollen-based synthesis for the last 11,000 years. Sci. Rep. 2018, 8, 716. [CrossRef] [PubMed]

5. Vannière, B.; Blarquez, O.; Rius, D.; Doyen, É.; Brücher, T.; Colombarioli, D.; Connor, S.; Feurdean, A.; Kickler, T.; Kaltenrieder, P.; et al. 7000-year human legacy of elevation-dependent European fire regimes. Quat. Sci. Rev. 2016, 132, 206-212. [CrossRef]

6. Bocquet-Appel, J.; Naji, S.; Linden, M.V.; Kozlowski, J. Understanding the rates of expansion of the farming system in Europe. J. Archaeol. Sci. 2012, 39, 531-546. [CrossRef]

7. Leppard, T.P. Mobility and migration in the Early Neolithic of the Mediterranean: Questions of motivation and mechanism. World Archaeol. 2014, 46, 484-501. [CrossRef]

8. Dünkeloh, A.; Jacobeit, J. Circulation dynamics of Mediterranean precipitation variability. Int. J. Climatol. 2003, 23, 1843-1866. [CrossRef]

9. Lionello, P.; Sanna, A. Mediterranean wave climate variability and its links with NAO and Indian Monsoon. Clim. Dyn. 2005, 25, 611-623. [CrossRef]

10. Quézel, P.; Médail, F. Écologie et Biogéographie des Forêts du Bassin Méditerranéen; Elsevier Masson: Paris, France, 2003.

11. Ulbrich, U.; Lionello, P.; Belušić, D.; Jacobeit, J.; Knippertz, P.; Kuglitsch, G.; Leckebusch, G.C.; Luterbacher, J.; Maugeri, M.; Maheras, P.; et al. Climate of the Mediterranean: Synoptic Patterns, Temperature, Precipitation, Winds, and Their Extremes. In Climate of the Mediterranean Region-from the Past to the Future; Elsevier: London, UK, 2012; pp. 301-334.

12. Broodbank, C. The Making of the Middle Sea: A History of the Mediterranean from the Beginning to the Emergence of the Classical World; Oxford University Press: New York, NY, USA, 2013.

13. Sharma, A.S.; Baker, D.N.; Bhattacharyya, A.; Bunde, A.; Dimri, V.P.; Gupta, H.K.; Gupta, V.K.; Lovejoy, S.; Main, I.G.; Schertzer, D.; et al. Complexity and Extreme Events in Geosciences: An Overview. Complex. Extreme Events Geosic. 2012. [CrossRef]

14. Borzenkova, I.; Zorita, E.; Borisova, O.; Kalnié, L.; Kisieliene, D.; Koff, T.; Kiznetsov, D.; Lemdahl, G.; Sapelko, T.; Stančikaitè, M.; et al. Climate Change during the Holocene (Past 12,000 Years). In Second Assessment of Climate Change for the Baltic Sea Basin; The BACC II Author Team, Ed.; Springer: Cham, Switzerland, 2015; pp. 25-49.

15. Gavin, D.G.; Hu, F.S. Bioclimatic Modelling Using Gaussian Mixture Distributions and Multiscale Segmentation. Glob. Ecol. Biogeogr. 2005, 14, 491-501. [CrossRef]

16. Iglesias, V.; Whitlock, C.; Bianchi, M.M.; Villarosa, G.; Outes, V. Climate and local controls of long-term vegetation dynamics in northern Patagonia (Lat $41^{\circ} \mathrm{S}$ ). Quat. Res. 2012, 78, 502-512. [CrossRef]

17. Collins, P.M.; Davis, B.A.S.; Kaplan, J.O. The mid-Holocene vegetation of the Mediterranean region and southern Europe, and comparison with the present day. J. Biogeogr. 2012, 39, 1848-1861. [CrossRef]

18. Gaillard, M.; Whitehouse, N.; Madella, M.; Morrison, K.; von Gunten, L. Past Land Use and Land Cover. Past Glob. Chang. Mag. 2018, 26, 8-9.

19. García-Alix, A.; Jiménez-Espejo, F.J.; Toney, J.L.; Jiménez-Moreno, G.; Ramos-Román, M.J.; Scott Anderson, R.; Ruano, P.; Queralt, I.; Delgado Huertas, A.; Kuroda, J. Alpine bogs of southern Spain show human-induced environmental change superimposed on long-term natural variations. Sci. Rep. 2017, 7, 7439. [CrossRef] [PubMed]

20. Giesecke, T.; Davis, B.; Brewer, S.; Finsinger, W.; Wolters, S.; Blaauw, M.; de Beaulieu, J.L.; Binney, H.; Fyfe, R.M.; Gaillard, M.-J.; et al. Towards mapping the late Quaternary vegetation change of Europe. Veg. Hist. Archaeobot. 2014, 23, 75-86. [CrossRef]

21. Marlon, J.R.; Kelly, R.; Daniau, A.L.; Vannière, B.; Power, M.J.; Bartlein, P.; Higuera, P.; Blarquez, O.; Brewer, S.; Brücher, T.; et al. Reconstructions of biomass burning from sediment-charcoal records to improve data-model comparisons. Biogeosciences 2016, 13, 3225-3244. [CrossRef]

22. Kaplan, J.O.; Krumhardt, K.M.; Ellis, E.C.; Ruddiman, W.F.; Lemmen, C.; Goldewijk, K.K. Holocene carbon emissions as a result of anthropogenic land cover change. Holocene 2011, 21, 775-791. [CrossRef]

23. Brücher, T.; Brovkin, V.; Kloster, S.; Marlon, J.R.; Power, M.J. Comparing modelled fire dynamics with charcoal records for the Holocene. Clim. Past 2014, 10, 811-824. [CrossRef]

24. Kaplan, J.O.; Krumhardt, K.M. The KK10 Anthropogenic Land Cover Change scenario for the preindustrial Holocene, link to data in NetCDF format. Pangea 2011, 21, 775-791. 
25. Kaplan, J.O.; Krumhardt, K.M.; Zimmermann, N. The prehistoric and preindustrial deforestation of Europe. Quat. Sci. Rev. 2009, 28, 3016-3034. [CrossRef]

26. Parisien, M.A.; Moritz, M.A. Environmental controls on the distribution of wildfire at multiple spatial scales. Ecol. Monogr. 2009, 79, 127-154. [CrossRef]

27. Vanniére, B.; Power, M.J.; Roberts, N.; Tinner, W.; Carrión, J.; Magny, M.; Bartlein, D.; Colombarioli, D.; Daniau, A.L.; Finsinger, W.; et al. Circum-mediterranean fire activity and climate changes during the mid-Holocene environmental transition (8500-2500 cal. BP). Holocene 2011, 21, 53-73. [CrossRef]

28. Fyfe, R.M.; de Beaulieu, J.-L.; Binney, H.; Bradshaw, R.H.W.; Brewer, S.; Le Flao, A.; Finsinger, W.; Gaillard, M.-J.; Giesecke, T.; Gil-Romera, G.; et al. The European pollen database: Past efforts and current activities. Veg. Hist. Archaeobot. 2009, 18, 417-424. [CrossRef]

29. Whitlock, C.; Larsen, C. Charcoal as a fire proxy. In Tracking Environmental Change Using Lake Sediments. Volume 3: Terrestrial, Algal, and Siliceous Indicators; Smol, J., Birks, H., Last, W., Eds.; Kluwer Academic Publishers: Dordrecht, The Netherlands, 2001; pp. 75-99.

30. Box, G.E.; Cox, D.R. An analysis of transformations. J. R. Stat. Soc. 1964, 26, 211-252. [CrossRef]

31. Marlon, J.R.; Bartlein, P.J.; Carcaillet, C.; Gavin, D.G.; Harrison, S.P.; Higuera, P.E.; Joos, F.; Power, M.J.; Prentice, I.C. Climate and human influences on global biomass burning over the past two millennia. Nat. Geosci. 2008, 1, 697. [CrossRef]

32. Power, M.J.; Marlon, J.; Ortiz, N.; Bartlein, P.J.; Harrison, S.P.; Mayle, F.E.; Ballouche, A.; Bradshaw, R.H.W.; Carcaillet, C.; Cordova, C.; et al. Changes in fire regimes since the Last Glacial Maximum: An assessment based on a global synthesis and analysis of charcoal data. Clim. Dyn. 2008, 30, 887-907. [CrossRef]

33. Mercuri, A.M.; Florenzano, A.; Burjachs, F.; Giardini, M.; Kouli, K.; Masi, A.; Picornell-Gelabert, L.; Revelles, J.; Sadori, L.; Servera-Vives, G.; et al. From influence to impact: The multifunctional land use in Mediterranean prehistory emerging from palynology of archaeological sites (8.0-2.8 ka BP). Holocene 2019, 29, 830-846. [CrossRef]

34. Pantaléon-Cano, J.; Yll, E.I.; Pérez-Obiol, R.; Roure, J.M. Palynological evidence for vegetational history in semi-arid areas of the western Mediterranean (Almería, Spain). Holocene 2003, 13, 109-119. [CrossRef]

35. Mercuri, A.M.; Bandini Mazzanti, M.; Florenzano, A.; Montecchi, M.C.; Rattighieri, E. Olea, Juglans and Castanea: The OJC group as pollen evidence of the development of human-induced environments in the Italian peninsula. Quat. Int. 2013, 303, 24-42. [CrossRef]

36. Iglesias, V.; Whitlock, C. Fire responses to postglacial climate change and human impact in northern Patagonia (41-43 ${ }^{\circ}$ S). Proc. Natl. Acad. Sci. USA 2014, 111, E5545-E5554. [CrossRef] [PubMed]

37. Wood, S. Fast stable restricted maximum likelihood and marginal likelihood estimation of semiparametric generalized linear models. J. R. Stat. Soc. 2011, 73, 3-36. [CrossRef]

38. Akaike, H. Information theory as an extension of the maximum likelihood principle. In Second International Symposium on Information Theory; Petrov, B.N., Csaki, F., Eds.; Akademiai Kiado: Budapest, Hungary, 1973; pp. 267-281.

39. Burnham, K.P.; Anderson, D.R. Model Selection and Multimodal Inference: A Practical Information-Theoretic Approach; Springer: New York, NY, USA, 2002.

40. Sugita, S.; Gaillard, M.J.; Broström, A. Landscape openness and pollen records: A simulation approach. Holocene 1999, 9, 409-421. [CrossRef]

41. Higuera, P.E.; Sprugel, D.G.; Brubaker, L.B. Reconstructing fire regimes with charcoal from small-hollow sediments: A calibration with tree-ring records of fire. Holocene 2005, 15, 238-251. [CrossRef]

42. Iglesias, V.; Quintana, F.; Nanavati, W.; Whitlock, C. Interpreting modern and fossil pollen data along a steep environmental gradient in northern Patagonia. Holocene 2017, 27, 1008-1018. [CrossRef]

43. Grimm, E.C. CONISS: A FORTRAN 77 program for stratigraphically constrained cluster analysis by the method of incremental sum of squares. Comput. Geosci. 1987, 13, 13-35. [CrossRef]

44. Bennett, K.D. Determination of the number of zones in a biostratigraphical sequence. New Phytol. 1996, 132, 155-170. [CrossRef]

45. Priyadarshana, W.J.R.M.; Sofronov, G. Multiple Break-Points Detection in Array CGH Data via the Cross-Entropy Method. IEEE/ACM Trans. Comput. Biol. Bioinform. 2015, 12, 487-498. [CrossRef]

46. Breiman, L.; Friedman, J.; Stone, C.; Olshen, R. Classification and Regression Trees; Belmont: Wadsworth, $\mathrm{OH}$, USA, 1984.

47. Ripley, B. Pattern Recognition and Neural Networks; Cambridge University Press: Cambridge, UK, 1996. 
48. Marlon, J.; Bartlein, P.J.; Whitlock, C. Fire-fuel-climate linkages in the northwestern USA during the Holocene. Holocene 2006, 16, 1059-1071. [CrossRef]

49. Ali, A.A.; Blarquez, O.; Girardin, M.P.; Hély, C.; Tinquaunt, F.; El Guellab, A.; Valsecchi, V.; Terrier, A.; Bremond, L.; Genries, A.; et al. Control of the multimillennial wildfire size in boreal North America by spring climatic conditions. Proc. Natl. Acad. Sci. USA 2012, 109, 20966-20970. [CrossRef]

50. R Core Team. R: A Language and Environment for Statistical Computing; R Foundation for Statistical Computing: Vienna, Austria, 2016.

51. Dag, O.; Asar, O.; Ozlem, I. AID: An R Package to Estimate Box-Cox Power Transformation Parameter; R package version 2.4; 2014; Available online: https://CRAN.R-project.org/package=AID (accessed on 10 August 2019).

52. Maechler, M. Akima: Interpolation of Irregularly Spaced Data; R package version 0.6-2; 2013; Available online: https://CRAN.R-project.org/package=akima (accessed on 10 August 2019).

53. Weisberg, S. Applied Linear Regression; Wiley: Hoboken, NJ, USA, 2005.

54. Wickham, H.; Francois, R. Dplyr: A Grammar of Data Manipulation; R package version 0.8.3; 2015; Available online: http://dplyr.tidyverse.org, https://github.com/tidyverse/dplyr; (accessed on 10 August 2019).

55. Wickham, H. Ggplot2: Elegant Graphics for Data Analysis; Springer: New York, NY, USA, 2009.

56. Juggins, S. rioja: Analysis of Quaternary Science Data, R package version 0.9-21; 2017; Available online: http://cran.r-project.org/package=rioja (accessed on 10 August 2019).

57. Ripley, B. Tree: Classification and Regression Trees; R package version 1.0-40; 2014; Available online: https: //CRAN.R-project.org/package=tree (accessed on 10 August 2019).

58. Berger, A.; Loutre, M. Insolation values for the climate of the last 10 million years. Quat. Sci. Rev. 1991, 10, 297-317. [CrossRef]

59. Manzano, S.; Carrión, J.S.; López-Merino, L.; Jiménez-Moreno, G.; Toney, J.L.; Amstrong, H.; Anderson, R.S.; García-Aliz, A.; Guerrero Pérez, J.L.; Sánchez-Mata, D. A palaeoecological approach to understanding the past and present of Sierra Nevada, a Southwestern European biodiversity hotspot. Glob. Planet. Chang. 2019, 175, 238-250. [CrossRef]

60. Cacho, I.; Grimalt, J.O.; Canals, M.; Sbaffi, L.; Shackleton, N.J.; Schönfeld, J.; Zahn, R. Variability of the Western Mediterranean sea surface temperature during the last 25,000 years and its connection with the Northern Hemisphere climatic changes. Paleoceanography 2001, 16, 40-52. [CrossRef]

61. Renssen, H.; Seppä, H.; Heiri, O.; Roche, D.M.; Goosse, H.; Fichefet, T. The spatial and temporal complexity of the holocene thermal maximum. Nat. Geosci. 2009, 2, 411. [CrossRef]

62. Samartin, S.; Heiri, O.; Joos, F.; Franke, J.; Brönnimann, S.; Tinner, W. Warm Mediterranean mid-Holocene summers inferred from fossil midge assemblages. Nat. Geosci. 2017, 10, 207. [CrossRef]

63. Brayshaw, D.J.; Rambeau, C.M.C.; Smith, S.J. Changes in Mediterranean climate during the Holocene: Insights from global and regional climate modelling. Holocene 2011, 21, 15-31. [CrossRef]

64. Magny, M.; Vannière, B.; Calo, C.; Millet, L.; Peyron, O.; Zanchetta, G.; La Mantia, T.; Tinner, W. Holocene hydrological changes in south-western Mediterranean as recorded by lake-level fluctuations at Lago Preola, a coastal lake in southern Sicily, Italy. Quat. Sci. Rev. 2011, 30, 2459-2475. [CrossRef]

65. Jones, S.E.; Burjachs, F.; Ferrer-García, C.; Giralt, S.; Schulte, L.; de Pablo, J.F.-L. A multi-proxy approach to understanding complex responses of salt-lake catchments to climate variability and human pressure: A Late Quaternary case study from south-eastern, Spain. Quat. Sci. Rev. 2018, 184, 201-223. [CrossRef]

66. Finné, M.; Woodbridge, J.; Labuhn, I.; Roberts, C.N. Holocene hydro-climatic variability in the Mediterranean: A synthetic multi-proxy reconstruction. Holocene 2019, 29, 847-863. [CrossRef]

67. Benito, G.; Macklin, M.G.; Zielhofer, C.; Jones, A.F.; Machado, M.J. Holocene flooding and climate change in the Mediterranean. Catena 2015, 130, 13-33. [CrossRef]

68. Vannière, B.; Magny, M.; Joannin, S.; Simonneau, A.; Wirth, S.B.; Hamann, Y.; Chapron, E.; Gilli, A.; Desmet, M.; Anselmetti, F.S. Orbital changes, variation in solar activity and increased anthropogenic activities: Controls on the Holocene flood frequency in the Lake Ledro area, Northern Italy. Clim. Past 2013, 9, 1193-1209. [CrossRef]

69. Tinner, W.; van Leeuwen, J.F.N.; Colombarioli, D.; Vescovi, E.; van der Knaap, W.O.; Henne, P.D.; Pasta, S.; D’Angelo, S.; La Mantia, T. Holocene environmental and climatic changes at Gorgo Basso, a coastal lake in southern Sicily, Italy. Quat. Sci. Rev. 2009, 28, 1498-1510. [CrossRef]

70. Coughlan, M.R.; Magi, B.I.; Derr, K.M. A Global Analysis of Hunter-Gatherers, Broadcast Fire Use, and Lightning-Fire-Prone Landscapes. Fire 2018, 1, 41. [CrossRef] 
71. Bird, R.; Bird, D.; Codding, B.; Parker, C.; Jones, J. The 'Fire Stick Farming' Hypothesis: Australian Aboriginal Foraging Strategies, Biodiversity, and Anthropogenic Fire Mosaics. Proc. Natl. Acad. Sci. USA 2008, 105, 14796-14801. [CrossRef] [PubMed]

72. Innes, J.B.; Blackford, J.J.; Rowley-Conwy, P.A. Late Mesolithic and early Neolithic forest disturbance: A high resolution palaeoecological test of human impact hypotheses. Quat. Sci. Rev. 2013, 77, 80-100. [CrossRef]

73. Joannin, S.; Vannière, B.; Galop, D.; Peyron, O.; Haas, J.N.; Gilli, A.; Chapron, E.; Wirth, S.B.; Anselmetti, F.; Desmet, M.; et al. Climate and vegetation changes during the lateglacial and early-middle holocene at lake ledro (southern alps, Italy). Clim. Past 2013, 9, 913-933. [CrossRef]

74. Carrión, J.S. Patterns and processes of Late Quaternary environmental change in a montane region of southwestern Europe. Quat. Sci. Rev. 2002, 21, 2047-2066. [CrossRef]

75. Gil-Romera, G.; Carrión, J.S.; Pausas, J.; Sevilla-Callejo, M.; Lamb, H.F.; Fernández, S.; Burjachs, F. Holocene fire activity and vegetation response in South-Eastern Iberia. Quat. Sci. Rev. 2010, 29, 1082-1092. [CrossRef]

76. Carrión, J.S.; Fernández, S.; González-Sampériz, P.; Gil-Romera, G.; Badal, E.; Carrión-Marco, Y.; López-Merino, L.; López-Sáez, J.A.; Fierro, E.; Burjachs, F. Expected trends and surprises in the Lateglacial and Holocene vegetation history of the Iberian Peninsula and Balearic Islands. Rev. Palaeobot. Palynol. 2010, 162, 458-475. [CrossRef]

77. Williams, M. A New Look at Global Forest Histories of Land Clearing. Annu. Rev. Environ. Resour. 2008, 33, 345-367. [CrossRef]

78. Iversen, J. Forest Clearance in the Stone Age. Sci. Am. 1956, 194, 36-41. [CrossRef]

79. Whitlock, C.; Millspaugh, S. Testingtheassumptionsof fire-history studies: An examination of modern charcoal accumulation in Yellowstone National Park, USA. Holocene 1996, 6, 7-15. [CrossRef]

80. Carrion, J.S.; Dupre, M. Late Quaternary vegetational history at Navarrés, Eastern Spain. A two core approach. New Phytol. 1996, 134, 177-191. [CrossRef]

81. Connor, S.E.; Vannière, B.; Colombarioli, D.; Anderson, R.S.; Carrión, J.S.; Ejarque, A.; Gil-Romera, G.; Gonzáliz-Sampériz, P.; Hoefer, D.; Morales-Morino, C.; et al. Humans take control of fire-driven diversity changes in Mediterranean Iberia's vegetation during the mid-late Holocene. Holocene 2019, 29, 886-901. [CrossRef]

82. Gignoux, C.R.; Henn, B.M.; Mountain, J.L. Rapid, global demographic expansions after the origins of agriculture. Proc. Natl. Acad. Sci. USA 2011, 108, 6044-6049. [CrossRef]

83. Shennan, S.; Downey, S.S.; Timpson, A.; Edinborough, K.; Colledge, S.; Kerig, T.; Manning, K.; Thomas, M.G. Regional population collapse followed initial agriculture booms in mid-Holocene Europe. Nat. Commun. 2013, 4, 2486. [CrossRef]

84. Colombaroli, D.; Vannière, B.; Emmanuel, C.; Magny, M.; Tinner, W. Fire-vegetation interactions during the Mesolithic-Neolithic transition at Lago dell'Accesa, Tuscany, Italy. Holocene 2008, 18, 679-692. [CrossRef]

85. Vannière, B.; Colombaroli, D.; Chapron, E.; Leroux, A.; Tinner, W.; Magny, M. Climate versus human-driven fire regimes in Mediterranean landscapes: The Holocene record of Lago dell'Accesa (Tuscany, Italy). Quat. Sci. Rev. 2008, 27, 1181-1196. [CrossRef]

86. Zeder, M.A. Domestication and early agriculture in the Mediterranean Basin: Origins, diffusion, and impact. Proc. Natl. Acad. Sci. USA 2008, 105, 11597-11604. [CrossRef]

87. Jouffroy-Bapicot, I.; Vannière, B.; Gauthier, É.; Richard, H.; Monna, F.; Petit, C. 7000 years of vegetation history and land-use changes in the Morvan Mountains (France): A regional synthesis. Holocene 2013, 23, 1888-1902. [CrossRef]

88. Cyprien, A.L.; Carcaud, N.; Visset, L. Etude paléoenvironnementale du Marais de Distré (Saumurois): Géoarchéologie d'une zone humide depuis le Préboréal/Paleoenvironmental study of the marshland $\mathrm{m}$ Distré (Saumurois, France); geoarcheohgy of a humid zone since the preboreal period. Quaternaire 2001, 12, 89-101. [CrossRef]

89. Roos-Barraclough, F.; van der Knaap, W.O.; van Leeuwen, J.F.N.; Shotyk, W. A Late-glacial and Holocene record of climatic change from a Swiss peat humification profile. Holocene 2004, 14, 7-19. [CrossRef]

90. Magny, M.; Comborieu-Nebout, N.; de Beaulieu, J.L.; Bout-Roumazeilles, V.; Colombarioli, D.; Desprat, S.; Francke, A.; Joannin, S.; Ortu, E.; Peyron, O.; et al. North-south palaeohydrological contrasts in the central mediterranean during the holocene: Tentative synthesis and working hypotheses. Clim. Past 2013, 9, 2043-2071. [CrossRef] 
91. Palmisano, A.; Bevan, A.; Shennan, S. Regional Demographic Trends and Settlement Patterns in Central Italy: Archaeological Sites and Radiocarbon Dates. J. Open Archaeol. Data 2018, 6. [CrossRef]

92. Mighall, T.; Timberlake, S.; Martínez-Cortizas, A.; Silva-Sánchez, N.; Foster, I. Did prehistoric and Roman mining and metallurgy have a significant impact on vegetation? J. Archaeol. Sci. 2017, 11, 613-625. [CrossRef]

93. Brown, T. Tony Brown Clearances and Clearings: Deforestation in Mesolithic/Neolithic Britain. Oxf. J. Archaeol. 1997, 16, 133-146. [CrossRef]

94. Andrič, M. Holocene vegetation development in Bela krajina (Slovenia) and the impact of first farmers on the landscape. Holocene 2007, 17, 763-776. [CrossRef]

95. Valsecchi, V.; Finsinger, W.; Tinner, W.; Ammann, B. Testing the influence of climate, human impact and fire on the Holocene population expansion of Fagus sylvatica in the southern Prealps (Italy). Holocene 2008, 18, 603-614. [CrossRef]

96. Butzer, K.W. Environmental history in the Mediterranean world: Cross-disciplinary investigation of cause-and-effect for degradation and soil erosion. J. Archaeol. Sci. 2005, 32, 1773-1880. [CrossRef]

97. Chavarría, A.; Lewit, T.; Izdebski, A. Settlement, Land Use and Society in the Late Antique Mediterranean, 4th-7th c. An Overview. Late Antique Archaeol. 2018, 12, 132-147. [CrossRef]

98. Malthus, T. An Essay on the Principle of Population; Oxford World's Classics: Oxford, UK, 1798.

99. Boserup, E. The Conditions of Agricultural Growth: The Economics of Agrarian Change under Population Pressure; Allen \& Unwin: London, UK, 1965.

100. Carrión, J.S.; van Geel, B. Fine-resolution Upper Weichselian and Holocene palynological record from Navarres (Valencia, Spain) and a discussion about factors of Mediterranean forest succession. Rev. Palaeobot. Palynol. 1999, 106, 209-236. [CrossRef]

101. Goñi, M.F.S.; Eynaud, F.; Turon, J.L.; Shackleton, N.J. High resolution palynological record off the Iberian margin: Direct land-sea correlation for the Last Interglacial complex. Earth Planet. Sci. Lett. 1999, 171, 123-137. [CrossRef]

102. Stevenson, A.C. The Holocene forest history of the Montes Universales, Teruel, Spain. Holocene 2000, 10, 603-610. [CrossRef]

103. Davis, B.A.S.; Stevenson, A.C. The $8.2 \mathrm{ka}$ event and Early-Mid Holocene forests, fires and flooding in the Central Ebro Desert, NE Spain. Quat. Sci. Rev. 2007, 26, 1695-1712. [CrossRef]

104. Finsinger, W.; Tinner, W. Pollen and plant macrofossils at Lac de Fully (2135 m a.s.l.): Holocene forest dynamics on a highland plateau in the Valais, Switzerland. Holocene 2007, 17, 1119-1127. [CrossRef]

105. Joannin, S.; Brugiapaglia, E.; de Beaulieu, J.-L.; Magni, M.; Peyron, O.; Vannière, B. Pollen-based reconstruction of Holocene vegetation and climate in southern Italy: The case of Lago Trifoglietti. Clim. Past 2012, 8, 1973-1996. [CrossRef]

106. Nicol-Pichard, S.; Dubar, M. Reconstruction of Late-glacial and Holocene environments in south-east France based on the study of a 66-m long core from Biot, Alpes Maritimes. Veg. Hist. Archaeobot. 1998, 7, 11-15. [CrossRef]

107. Lotter, A.F.; Heiri, O.; Hofmann, W.; van der Knaap, W.O.; van Leeuwen, J.F.N.; Walker, I.R.; Wick, L. Holocene timber-line dynamics at Bachalpsee, a lake at $2265 \mathrm{~m}$ a.s.l. in the northern Swiss Alps. Veg. Hist. Archaeobot. 2006, 15, 295-307. [CrossRef]

108. Tinner, W.; Kaltenrieder, P. Rapid responses of high-mountain vegetation to early Holocene environmental changes in the Swiss Alps. J. Ecol. 2005, 93, 936-947. [CrossRef]

109. Stähli, M.; Finsinger, W.; Tinner, W.; Allgöwer, B. Wildfire history and fire ecology of the Swiss National Park (Central Alps): New evidence from charcoal, pollen and plant macrofossils. Holocene 2006, 16, 805-817. [CrossRef]

110. Colombaroli, D.; Marchetto, A.; Tinner, W. Long-term interactions between Mediterranean climate, vegetation and fire regime at Lago di Massaciuccoli (Tuscany, Italy). J. Ecol. 2007, 95, 755-770. [CrossRef]

111. Sánchez, M.C.; Jiménez-Espejo, F.J.; Simón Vallejo, M.D.; Gibaja Bao, J.F.; Carvalho, A.F.; Martínez-Ruiz, F.; Rodrigo Gamiz, M.; Flores, J.-A.; Paytan, A.; López Sáez, J.A.; et al. The Mesolithic-Neolithic transition in southern Iberia. Quat. Res. 2012, 77, 221-234. [CrossRef]

112. Martrat, B.; Grimalt, J.; Shackleton, N.; de Abreu, L.; Hutterli, M.; Stocker, T. Four climate cycles of recurring deep and surface water destabilizations on the Iberian margin. Science 2007, 317, 502-507. [CrossRef] [PubMed] 
113. Pérez-Díaz, S.; López-Sáez, J.A.; Pontevedra-Pombal, X.; Souto-Souto, M.; Galop, D. 8000 years of vegetation history in the northern Iberian Peninsula inferred from the palaeoenvironmental study of the Zalama ombrotrophic bog (Basque-Cantabrian Mountains, Spain). Boreas 2016, 45, 658-672. [CrossRef]

114. Ibáñez, B.; Gómez-Aparicio, L.; Stoll, P.; Ávila, J.M.; Pérez-Ramos, I.M.; Marañón, T. A Neighborhood Analysis of the Consequences of Quercus suber Decline for Regeneration Dynamics in Mediterranean Forests. PLoS ONE 2015, 10, e0117827. [CrossRef]

115. Noël, H.; Garbolino, E.; Brauer, A.; Lallier-Vergès, E.; de Beaulieu, J.L.; Disnar, J.R. Human impact and soil erosion during the last 5000 yrs as recorded in lacustrine sedimentary organic matter at Lac d'Annecy, the French Alps. J. Paleolimnol. 2001, 25, 229-244. [CrossRef]

116. Carrión, J.S.; Sánchez-Gómez, P.; Mota, J.F.; Yll, R.; Chaín, C. Holocene vegetation dynamics, fire and grazing in the Sierra de Gádor, southern Spain. Holocene 2003, 13, 839-849. [CrossRef]

117. Noti, R.; van Leeuwen, J.F.N.; Colombarioli, D.; Vescovi, E.; Pasta, S.; La Mantia, T.; Tinner, W. Mid- and late-holocene vegetation and fire history at Biviere di Gela, a coastal lake in southern Sicily, Italy. Veg. Hist. Archaeobot. 2009, 18, 371-387. [CrossRef]

118. Sadori, L.; Jahns, S.; Peyron, O. Mid-Holocene vegetation history of the central Mediterranean. Holocene 2011, 21, 117-129. [CrossRef]

119. Calò, C.; Henne, P.D.; Curry, B.; Magny, M.; Vescovi, E.; La Mantia, T.; Pasta, S.; Vanniére, B.; Tinner, W. Spatio-temporal patterns of Holocene environmental change in southern Sicily. Palaeogeogr. Palaeoclimatol. Palaeoecol. 2012, 323, 110-122. [CrossRef]

120. Jiménez-Moreno, G.; García-Alix, A.; Hernández-Corbalán, M.D.; Anderson, R.S.; Delgado-Huertas, A. Vegetation, fire, climate and human disturbance history in the southwestern Mediterranean area during the late Holocene. Quat. Res. 2013, 79, 110-122. [CrossRef]

121. Ramos-Román, M.J.; Jiménez-Moreno, G.; Camuera, J.; García-Alix, A.; Anderson, R.S.; Jiménez-Espejo, F.J.; Carrión, J.S. Holocene climate aridification trend and human impact interrupted by millennial- and centennial-scale climate fluctuations from a new sedimentary record from Padul (Sierra Nevada, southern Iberian Peninsula). Clim. Past 2018, 14, 117-137. [CrossRef]

122. Kaal, J.; Carrión Marco, Y.; Asouti, E.; Seijo, M.M.; Martínez Cortizas, A.; Costa Casáis, M.; Criado Boado, F. Long-term deforestation in NW Spain: Linking the Holocene fire history to vegetation change and human activities. Quat. Sci. Rev. 2011, 30,161-175. [CrossRef]

123. Simonneau, A.; Doyen, E.; Chapron, E.; Millet, L.; Vannière, B.; Di Giovani, C.; Bossard, N.; Tachikawa, K.; Bard, E.; Albéric, P.; et al. Holocene land-use evolution and associated soil erosion in the French Prealps inferred from Lake Paladru sediments and archaeological evidences. J. Archaeol. Sci. 2013, 40, 1636-1645. [CrossRef]

124. Watts, W.A.; Allen, J.R.M.; Huntley, B.; Fritz, S.C. Vegetation history and climate of the last 15,000 years at Laghi di Monticchio, southern Italy. Quat. Sci. Rev. 1996, 15, 113-132. [CrossRef]

125. Dapples, F.; Lotter, A.F.; van Leeuwen, J.F.N.; van der Knaap, W.O.; Dimitriadis, S.; Oswald, D. Paleolimnological evidence for increased landslide activity due to forest clearing and land-use since $3600 \mathrm{cal} \mathrm{bp}$ in the western Swiss Alps. J. Paleolimnol. 2002, 27, 239-248. [CrossRef]

126. Franco-Múgica, F.; García-Antón, M.; Maldonado-Ruiz, J.; Morla-Juaristi, C.; Sainz-Ollero, H. Ancient pine forest on inland dunes in the Spanish northern meseta. Quat. Res. 2005, 63, 1-14. [CrossRef]

(C) 2019 by the authors. Licensee MDPI, Basel, Switzerland. This article is an open access article distributed under the terms and conditions of the Creative Commons Attribution (CC BY) license (http://creativecommons.org/licenses/by/4.0/). 